\title{
Evaluation of Ergonomic Risk Factors, Acute Traumatic Injuries, and Occupational Exposures at an Airline Catering Facility
}

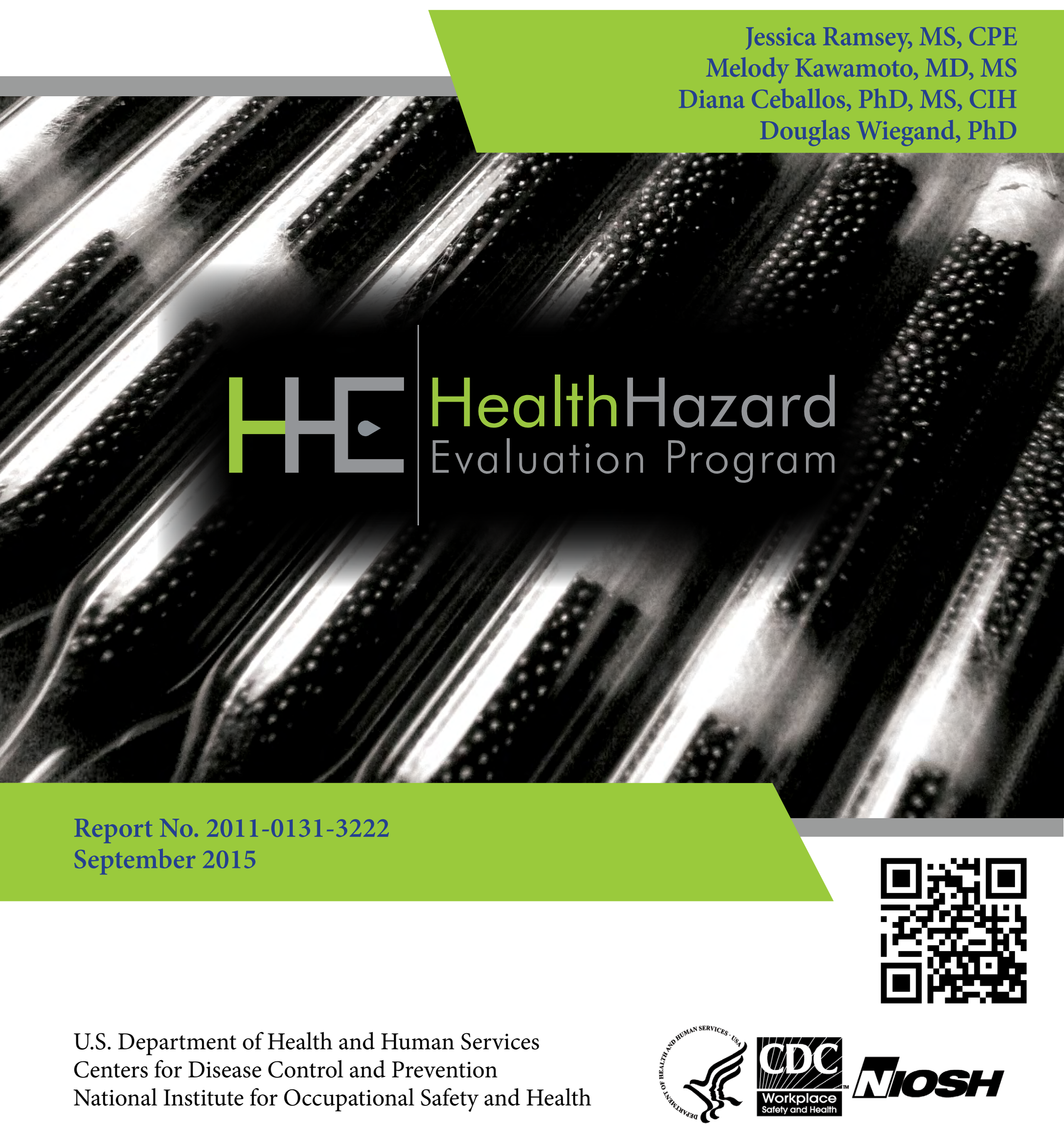




\section{Contents}

Highlights.

Abbreviations ...................................... iii

Introduction ................................... 1

Methods $\ldots \ldots \ldots \ldots \ldots \ldots \ldots \ldots \ldots \ldots \ldots \ldots \ldots \ldots \ldots \ldots \ldots \ldots \ldots \ldots \ldots$

Results and Discussion ........................ 5

Conclusions ....................................... 24

Recommendations ........................... 25

Appendix A ........................................ 30

References.......................................... 33

Acknowledgements............................ 39

The employer is required to post a copy of this report for 30 days at or near the workplace(s) of affected employees. The employer must take steps to ensure that the posted report is not altered, defaced, or covered by other material.

The cover photo is a close-up image of sorbent tubes, which are used by the HHE Program to measure airborne exposures. This photo is an artistic representation that may not be related to this Health Hazard Evaluation. Photo by NIOSH. 


\section{Highlights of this Evaluation}

The Health Hazard Evaluation Program received a request from a union to evaluate airline catering facilities. The union was concerned about risk factors for work-related musculoskeletal disorders, injuries, exposures to cold and hot environments, job stress, interpersonal relationships at work, and language barriers to communication. This report is for the second of two facilities we evaluated for this request. We evaluated the facility in January 2013.

\section{What We Did}

- We observed job tasks to document risk factors for work-related musculoskeletal disorders.

- We measured workstation heights and reach distances to determine injury risk.

- We measured air temperature, air flow, and carbon dioxide in the coolers.

- We measured carbon monoxide at the loading docks.

- We reviewed 5 years of work-related injury and illness information.

- We interviewed employees about their work, their health, and the union's concerns.

\section{What We Found}

- Employees' tasks involved awkward postures and repetitive motions that could increase their risk for work-related musculoskeletal disorders of the back, shoulders, and arms.

- Most interviewed employees reported that they had musculoskeletal symptoms during the week before our evaluation.

We evaluated risk factors for work-related musculoskeletal disorders, injuries, and other employee concerns at an airline catering facility. We found risk factors and hazards that could explain employees' symptoms, work-related musculoskeletal disorders, and acute traumatic injuries. We also found problems related to cold exposure, dry ice, job stress, and communication. We recommend addressing the exposures discussed in this report and providing training that all employees can understand.

- The illness and injury logs showed that $22 \%$ of all recorded musculoskeletal injuries were related to known risk factors for work-related musculoskeletal disorders.

- Most incidents recorded on the illness and injury logs were acute traumatic injuries.

- Our sampling results showed high levels of carbon dioxide in enclosed, unventilated coolers.

- Employees said that they did not have enough water to drink during their work shift.

- Employees reported time pressure, high workload, and a lack of equipment or supplies as sources of job stress.

- Some employees felt a lack of support from coworkers. 
- Some employees reported difficulty communicating because of language differences, which could affect occupational safety and health, including the effectiveness of training.

- The amount of information, complexity of content, and design of training materials created barriers to communication and training.

\section{What the Employer Can Do}

- Design work areas to have a standing hand working height of 38 to 47 inches or provide adjustable height tables.

- Rotate employees to different job tasks that use different muscle groups.

- Provide employees in cold environments with ways to warm their hands, such as warm water, heaters, glove options, and breaks.

- Use and store dry ice only in designated well ventilated rooms.

- Label dry ice packaging and post warning signs in areas where the use of dry ice is permitted.

- Enforce the prohibition of dry ice inside walk-in coolers and post signs about this prohibition at cooler entrances and inside the coolers.

- Provide employees with drinking water in work areas.

- Identify and address the specific causes of job stress.

- Assure that all safety information, labels, warning signs, and trainings are in English and Spanish.

- Improve the content and delivery of training to ensure understanding by all employees.

- Include employees in labor-management safety and health committees.

\section{What Employees Can Do}

- Modify your work practices so that you only lift and carry things above the knees, below the shoulders, and close to the body.

- Do not wear wet clothes in the coolers.

- Take part in safety and health committees.

- Tell your supervisor or the trainer if you do not understand written information such as labels, warning signs, and training materials or verbal information during training.

- Report hazards or hazardous conditions to your supervisor as soon as you notice them.

- Report symptoms and injuries to your supervisor as soon as they occur. 


\section{Abbreviations}

$\begin{array}{ll}\text { ACGIH® } & \begin{array}{l}\text { American Conference of Governmental Industrial Hygienists } \\ { }^{\circ} \mathrm{C}\end{array} \\ \mathrm{CO}_{2} & \text { Centigrade degrees } \\ \mathrm{CO} & \text { Carbon dioxide } \\ \mathrm{CFR} & \text { Carbon monoxide } \\ { }^{\circ} \mathrm{F} & \text { Code of Federal Regulations } \\ \text { NIOSH } & \text { National Institute for Occupational Safety and Health } \\ \text { OEL } & \text { Occupational exposure limit } \\ \text { OSHA } & \text { Occupational Safety and Health Administration } \\ \text { PEL } & \text { Permissible exposure limit } \\ \text { PPE } & \text { Personal protective equipment } \\ \text { REL } & \text { Recommended exposure limit } \\ \text { STEL } & \text { Short-term exposure limit } \\ \text { TLV }{ }^{\circ} & \text { Threshold limit value } \\ \text { WEEL } & \text { Workplace environmental exposure level }\end{array}$




\section{This page left intentionally blank}




\section{Introduction}

The Health Hazard Evaluation Program received a request from a union representing employees of an airline catering company. The union was concerned about musculoskeletal disorders, injuries related to working in the kitchen and on the loading docks, extreme hot and cold temperatures, job stress, and interpersonal relationships at work. In September 2011, we evaluated an airline catering facility in Michigan. The results of that evaluation were provided in a separate report [NIOSH 2014b]. In January 2013, we evaluated a facility in New York for the same concerns. At this facility, the union had additional concerns about carbon dioxide $\left(\mathrm{CO}_{2}\right)$ exposures related to the use of dry ice in coolers, and about language barriers to communication for employees whose primary language was not English. We sent a letter, written in English and Spanish, with a brief summary of our New York site visit activities and preliminary recommendations on March 11, 2013. This report contains the final results and recommendations of our evaluation of the New York facility.

At the time of our January 2013 visit, production took place in a 50,000-square-foot building with 181 employees working on the first of two shifts. The company serviced 20 international flights and 101 domestic flights per day. Most employees prepared food, beverages, and food service items; placed them in drawers; and loaded drawers into food service carts. Drivers loaded the carts onto trucks and delivered the carts to planes prior to departure. Other employees unloaded drawers off carts from arriving flights, loaded dishwashers, and sanitized equipment. Employees typically worked 8-hour shifts with a 30-minute lunch break and an additional 20-minute break per 8-hour shift. Drivers' breaks varied depending on delivery schedules. Voluntary overtime was occasionally available.

\section{Methods}

Our primary objectives were to evaluate potential exposures to risk factors for work-related musculoskeletal disorders, hot and cold temperatures, dry ice, and job stress. Our work included (1) observing work practices and procedures, (2) sampling for cold temperatures and carbon dioxide, (3) confidential interviews with employees, and (4) reviewing company documents about occupational safety and health. We evaluated the facility during the day shift; work activities on the second shift were similar.

\section{Confidential Employee Interviews}

We selected participants from a roster of all first-shift employees. We included employees representing all job titles within each department except maintenance and varying lengths of employment within each job title. Participation was voluntary. Spanish was the primary language for most employees, and we offered them interviews in Spanish. Although language was not a selection criterion, we could interview employees only if they understood and spoke English or Spanish. We asked employer and union representatives for translations and synonyms of work-related words and terms that employees would understand. One of the two National Institute for Occupational Safety and Health (NIOSH) interviewers spoke Spanish; a certified interpreter assisted the other NIOSH interviewer. 
During the interviews, we asked about employees' work, symptoms, injuries, use of personal protective equipment (PPE), concerns about workplace health and safety, job stress,

psychosocial factors at work, and language and communication.

\section{Review of Company Records}

We evaluated the facility's Occupational Safety and Health Administration (OSHA) Form 300 Logs of Work-related Injuries and Illnesses for the years 2008 to 2012. The Logs included incidents from both shifts and incidents involving nonsupervisory and supervisory employees. We focused on recorded incidents that occurred in work areas. We did not include injuries that occurred in the parking lot and locker room because they were not relevant to the departments we evaluated. We describe the details of our evaluation of the OSHA Logs in the methods sections for ergonomics and acute traumatic injuries below.

We reviewed the company's documents about its occupational safety and health program, such as standard operating procedures, training materials, safety and health information, and reports of ergonomic and safety evaluations by an insurance company. Most of the materials were for company-wide use; some were specifically developed for this facility.

\section{Ergonomics}

We observed workplace conditions and work processes and practices for ergonomic risk factors. We measured workstation heights and reach distances and noted the availability of anti-fatigue mats and other PPE. A full description of the ergonomic evaluation criteria we used to determine risk factors for work-related musculoskeletal disorders is provided in Appendix A.

During the employee interviews, we asked about risk factors for musculoskeletal disorders including lifting heavy objects such as beverage cases and snack trays, extreme postures used to reach for things, and bending or stretching the body in awkward positions. Because job rotation could provide a reduction in repetitive tasks using the same muscle groups as well as provide recovery time, we asked about rotation of tasks within a shift and from day to day. We asked if, in the week before the interview, the employee had shoulder, back, neck, hand, and wrist pain or numbness or tingling in the hand or wrist, which could suggest work-related musculoskeletal disorders. We also asked a separate, open-ended question about health problems the employee had and if the employee considered them to be work-related.

We evaluated the OSHA Logs for musculoskeletal injuries and disorders (such as strain, sprain, musculoskeletal pain, tendinitis, carpal tunnel syndrome, and hernia) that might have been caused by risk factors for work-related musculoskeletal disorders. We classified injuries and disorders as possibly work-related musculoskeletal if the reported cause was a work-related risk factor, such as lifting, pushing, pulling, awkward posture, or repetitive movements; and the action was part of the usual work tasks in the employee's department. We evaluated these log entries by part of body affected, action listed in the description of the incident, and employee's department. We also calculated the cumulative number of days away from work, job transfer, and job restriction. We evaluated injuries caused by single, specific incidents separately (Acute Traumatic Injuries, below). 


\section{Acute Traumatic Injuries}

During the confidential employee interviews, we asked about work-related injuries that employees thought were related to their job, what they thought caused the injury, and how long the injury kept them from their usual work. We also asked if, in the week before the interview, they had cuts or burns to the hands or arms. This was part of a yes-or-no question to screen for a variety of health outcomes (including musculoskeletal symptoms) that could be found in the industry. We did not differentiate cuts from burns and did not ask about cause, severity, and other details.

We evaluated the OSHA Logs for acute traumatic injuries, such as lacerations, contusions, fractures, crush injuries, and musculoskeletal injuries (sprain, strain, or pain). We included injuries that were caused by a single specific traumatic incident, such as a slip, trip, fall, laceration, puncture, being struck by an object, or reaching to catch a falling object. We evaluated the OSHA Log data by type of injury, action and agent listed in the description of the incident, and employee's department. We also calculated the cumulative number of days away from work, job transfer, and job restriction.

\section{Exposure to Cold Environments}

We evaluated all five coolers at the facility: a receiving cooler in the storeroom and receiving cooler department, two production coolers in the cold food kitchen, a thawing area in the hot food kitchen, and a holding cooler entered by cold food kitchen and transportation employees. We collected information on factors known to influence an individual's response to cold exposure: air temperature, air velocity, humidity, physical activity, work/rest schedule, and protective clothing [Canadian Centre for Occupational Health and Safety 2008]. We measured air velocities and temperatures inside the coolers using a TSI VelociCalc ${ }^{\circledR}$ Plus with a vane anemometer (model 8386A). We measured air velocities at a standing chest level to capture what employees may feel at their workstations. We reviewed the company's daily cooler temperature records for day and night shifts and obtained copies of temperature records for one summer month and one winter month in 2012. Because of technical problems with our HOBO H08-032-IS Pro Series Relative Humidity/Temperature Data Logger, we were unable to obtain useful temperature and relative humidity data from continuous measurements made in the coolers throughout the day. We observed employees' physical activity, work/rest schedule, and use of protective clothing. During the employee interviews, we asked employees if they felt discomfort while working in cold temperatures and if they had ever been sick at work because of temperatures that were too cold. We also asked about their use of protective clothing during work in the coolers. We did not evaluate the freezers, which employees entered only as needed and for brief periods of time. We did not evaluate outdoor exposures to cold.

\section{Exposure to Hot Environments}

We did not evaluate exposures to hot environments because we visited this facility in mid-winter. During the employee interviews, we asked if employees felt discomfort while working in hot temperatures and if they had ever been sick at work because of temperatures 
that were too hot. We also asked whether employees had enough water to drink during their shift. Heat stress is addressed in greater detail in our evaluation of the Michigan facility [NIOSH 2014b].

\section{Carbon Dioxide}

Dry ice, the solid form of $\mathrm{CO}_{2}$, was used to keep food and beverages cool. As dry ice turns into gas, air concentrations of $\mathrm{CO}_{2}$ can build up, particularly in unventilated or poorly ventilated small spaces, such as walk-in freezers or coolers. To evaluate the possibility of employee exposures, we took grab (i.e., instantaneous) samples for $\mathrm{CO}_{2}$ in all five coolers using a TSI Q-TRAK Plus Indoor Air Quality Monitor (model 8554) and Dräger gas detection tubes. For comparison, we also took $\mathrm{CO}_{2}$ measurements in other areas of the facility. A description of occupational exposure limits and health effects for $\mathrm{CO}_{2}$ is in Appendix A. More information on dry ice is also provided in Appendix A.

\section{Carbon Monoxide}

We used a BW Technologies direct-reading GasAlert Extreme meter to measure carbon monoxide (CO) from diesel-powered delivery trucks in the dock area. After performing spot checks along the dock at the beginning of the shift, we positioned the meters approximately 5 feet above the floor for the remainder of the workday. We also talked with employer representatives and employees to learn if they had any concerns about exhaust from the delivery trucks. A brief description of occupational exposure limits and health effects for $\mathrm{CO}$ is in Appendix A. More information on diesel exhaust is provided in the report of the other facility [NIOSH 2014b].

\section{Job Stress and Psychosocial Factors}

During the employee interviews, we asked employees to rate their level of job stress with the following question: "During the past week, including today, how would you rate your current job stress level on a scale from 0 (as low as it can be) to 10 (as high as it can be)?" Employees were shown a picture of the scale with images of a "happy" face and a "distressed" face at their respective ends of the scale. Responses of 0-3 indicated low job stress, 4-6 indicated moderate job stress, and scores of 7 or greater indicated high job stress [Clark et al. 2011]. An open-ended question followed, asking employees to list perceived job stressors.

We asked several questions about psychosocial factors in the workplace with a focus on interpersonal relationships with coworkers and supervisors, comfort with reporting health and safety concerns, and discrimination. These questions included yes/no or frequency of occurrence (never, not often, fairly often, very often) response options.

\section{Language, Communication, and Training}

During the employee interviews, we asked employees about their first and second languages, their country of origin, and whether they had problems communicating with others because they spoke a different language. We also asked whether training, training materials, and 
health and safety information were available in their primary language. We reviewed some of the company's training and informational materials on workplace safety and health.

\section{Results and Discussion}

\section{Confidential Employee Interviews}

We interviewed 66 (37\%) of 178 first-shift employees (3 maintenance employees excluded). Table 1 shows the number of all employees and interviewed employees by department. The median age of the interviewed employees was 49 years (range: 18-72 years of age), the median length of employment with the company was 11 years (range: $<1-41$ years), and $53 \%$ were male.

Table 1. Number of first-shift employees and interview participants by department, ${ }^{*}$ January 2013

\begin{tabular}{lccc}
\hline Department & $\begin{array}{c}\text { Number (\%) } \\
\text { of first-shift } \\
\text { employees }\end{array}$ & $\begin{array}{c}\text { Number (\%) } \\
\text { of interviewed } \\
\text { employees }\end{array}$ & $\begin{array}{c}\text { Percent of interviewed } \\
\text { employees by } \\
\text { department }\end{array}$ \\
\hline Storeroom and receiving cooler & $13(7)$ & $9(14)$ & 69 \\
Cold food kitchen & $56(32)$ & $18(27)$ & 32 \\
Hot food kitchen & $12(7)$ & $8(12)$ & 67 \\
Beverage & $36(20)$ & $11(17)$ & 31 \\
Equipment and sanitation & $26(15)$ & $10(15)$ & 38 \\
Transportation & $35(20)$ & $10(15)$ & 29 \\
\hline All departments & 178 & 66 & 36 \\
\hline
\end{tabular}

*The evaluation was limited to production employees; thus three maintenance employees were excluded.

\section{Ergonomics}

In the storeroom and receiving cooler, we saw pallets of material placed directly on the floor and stacked next to each other. The location of the pallets limited access to only one or two sides of the pallet, which required extended reaches (up to 35"), as well as lifting materials anywhere from floor level $\left(8^{\prime \prime}\right)$ to above shoulder level (58"). The standard operating procedures for lifting and moving bottled water stated that pallets should be accessible from all sides, and that cases of water should not be stacked above waist level. The standard operating procedure for bottled water was not followed for other palletized items, such as other beverages. Shelf heights in the storeroom and cooler ranged from 13.5"-74". In both areas, a ladder was available to reach the higher shelves, but no hook or grabber was available to pull items closer to the employee to eliminate extended reaches and improve ladder safety.

In the two production coolers of the cold food kitchen, we observed employees preparing and packaging meals. The assembly tables varied from 34"-36" in height and supporting shelves for materials varied from $39^{\prime \prime}-60$ " in height. The average depth of the tables was 17". Most of the shelves were set at an angle, allowing gravity to move the items closer to the employee. Employees placed packaged meals on racks and carts in slots from 4"-64" in height. Some of 
the workstations had anti-fatigue mats in front of the tables. In the cold food storage cooler, an employee worked at a milk and orange juice station that was 28 " in height. The employee had to reach above shoulder level to tear tray liners from a roll located at head level. This workstation did not have an anti-fatigue mat.

In the beverage area, we observed employees disassembling and assembling liquor and beverage drawers. In the liquor area, we noted that, in an emergency, the exit path of the liquor drawer employee could be blocked by carts. We also noted a roll of tray liners hanging from the liquor area ceiling, requiring the employee to reach above shoulder level. In the soda area, soda drawers from previous flights were placed on pallets directly on the floor. Employees had to lift drawers from floor level ( $\left.8^{\prime \prime}\right)$ to the $37^{\prime \prime}$ high disassembly table then lean over the $25^{\prime \prime}$ deep table to place soda cans in the flow rack, which moved cans by gravity to assemblers preparing new drawers. Flow rack heights on the disassembly side ranged from $39.5 "-62$ " and the vertical clearance between flow racks varied from $4 "-8$ ". On the assembly side, flow rack heights ranged from 37"-55", and the vertical clearance between all flow racks was $4 "$. The assembled soda drawers were placed on pallets directly on the floor, resulting in lifts ending as low as floor level ( $\left.8^{\prime \prime}\right)$. Disassemblers typically handled only one can per hand at a time, while assemblers sometimes grabbed two cans simultaneously with one hand, resulting in higher grip forces and awkward hand postures. We also noted that the beverage flow rack had sharp metal edges that could cut the employees, particularly on the assembly side. Not all liquor and beverage workstations had anti-fatigue mats.

In the equipment and sanitation department, we observed employees emptying inbound dirty carts, loading items into the dish machine, washing carts, and dumping trash. Employees placed sorted items from the inbound carts on a table 37" in height and 22" deep. Silverware, glassware, linen, soda, garbage, and other items were removed from drawers and placed into their respective bins. The bins for garbage and linen were behind the employees, requiring them to turn or twist to place items into the proper bins. The bins for silverware, glassware, and plates traveled down a flow rack toward the dish machine. The employee working the dish machine retrieved the bins, placed them on a table, and loaded individual items into the dish machine (positioned at 39" from the floor). At the end of the dish machine, clean items were sorted into racks. Shelf height for the racks varied; one particular rack had shelves at 25", 32", and 48". On the dock, we noted that the safety mechanisms to activate the compaction of garbage and recycling containers had been overridden. We attributed this to the inconvenient location of the switches, which required awkward and extended postures to reach. We notified managers about this, and they removed the override for the safety mechanisms.

In our confidential interviews with 66 employees, $41(62 \%)$ reported that they lifted heavy objects either "fairly often" or "very often," and 42 (63\%) reported that they reached, bent, or stretched their body in an awkward position either "fairly often" or "very often." Nearly half of the interviewed employees reported that they rotated jobs or tasks, though most said that they rotated jobs from day to day rather than within shifts. Others reported that they changed stations from day to day, but that the tasks from station to station were essentially the same. Job rotation would not decrease the risk of musculoskeletal disorders if employees continue to do tasks that involve the same repetitive motions of the same muscle groups. 
Of the interviewed employees, 54 (82\%) reported having musculoskeletal symptoms, and $44(68 \%)$ reported feeling fatigue in the week before our evaluation (Table 2). Symptom reports came from all departments. When asked if they believed their symptoms were related to work, 25 (39\%) responded "yes." When asked to elaborate on an open-ended question that allowed more than one symptom response, the most commonly reported symptoms that they related to work were back pain $(11,34 \%$ of all who reported back pain), shoulder pain $(5,19 \%$ of all who reported shoulder pain), and symptoms that suggested carpal tunnel syndrome $(4,18 \%$ of all who reported symptoms that could be related to carpal tunnel syndrome). They attributed their musculoskeletal symptoms to heavy lifting, bending, or stretching in awkward positions (work activities that were reported by more than $60 \%$ of the interviewed employees) or doing tasks that required repetitive motion.

Table 2. Number of interviewed employees who reported musculoskeletal symptoms or fatigue in the week before the evaluation, by department, January 2013

\begin{tabular}{|c|c|c|c|c|c|c|c|c|c|}
\hline Department & No. & $\begin{array}{l}\text { Back } \\
\text { pain } \\
(\%)\end{array}$ & $\begin{array}{l}\text { Shoulder } \\
\text { pain } \\
(\%)\end{array}$ & $\begin{array}{l}\text { Hand } \\
\text { pain } \\
(\%)\end{array}$ & $\begin{array}{l}\text { Joint } \\
\text { pain } \\
(\%)\end{array}$ & $\begin{array}{l}\text { Neck } \\
\text { pain } \\
(\%)\end{array}$ & $\begin{array}{c}\text { Numb- } \\
\text { ness } \\
\text { in wrists } \\
\text { or hands } \\
\quad(\%)\end{array}$ & $\begin{array}{l}\text { Any musculo- } \\
\text { skeletal } \\
\text { symptoms* } \\
(\%)\end{array}$ & $\begin{array}{c}\text { Fatigue } \\
(\%)\end{array}$ \\
\hline $\begin{array}{l}\text { Storeroom } \\
\text { and } \\
\text { receiving } \\
\text { cooler }\end{array}$ & 9 & $5(56)$ & $2(22)$ & $3(33)$ & - & $1(11)$ & $4(44)$ & $8(89)$ & $5(63) \dagger$ \\
\hline $\begin{array}{l}\text { Cold food } \\
\text { kitchen }\end{array}$ & 18 & 7 (39) & $6(33)$ & $4(24) \dagger$ & $5(28)$ & $4(22)$ & $7(39)$ & $13(72)$ & $13(72)$ \\
\hline $\begin{array}{l}\text { Hot food } \\
\text { kitchen }\end{array}$ & 8 & $3(38)$ & $3(38)$ & $6(75)$ & $3(38)$ & $3(38)$ & $2(25)$ & $7(88)$ & $4(50)$ \\
\hline Beverage & 11 & $6(55)$ & $5(46)$ & $5(46)$ & $4(36)$ & $2(18)$ & $3(27)$ & $8(73)$ & $8(73)$ \\
\hline $\begin{array}{l}\text { Equipment } \\
\text { and } \\
\text { sanitation }\end{array}$ & 10 & $6(60)$ & $7(70)$ & $5(50)$ & $5(50)$ & $6(60)$ & $5(50)$ & $9(90)$ & $8(80)$ \\
\hline Transportation & 10 & $5(50)$ & $4(40)$ & $3(30)$ & $3(30)$ & $2(20)$ & $1(10)$ & $9(90)$ & $6(60)$ \\
\hline $\begin{array}{l}\text { All } \\
\text { departments }\end{array}$ & 66 & $32(49)$ & $27(41)$ & $26(40)$ & $20(30)$ & $18(27)$ & $22(33)$ & $54(82)$ & $44(68)$ \\
\hline
\end{tabular}

*Includes back pain, shoulder pain, hand pain, joint pain, neck pain, or numbness in the wrists or hands. Does not include fatigue.

†One employee was excluded because of a data collection error.

The OSHA Logs for the previous 5 years, 2008-2012, contained reports of 94 injuries and no illnesses. Musculoskeletal injuries related to lifting and other known risk factors that were likely to be repeated during usual work tasks accounted for $21(22 \%)$ of all recorded injuries. Lifting was identified as the cause of $57 \%$ of the musculoskeletal injuries, and the low back was affected in $48 \%$ (Table 3). Although transportation employees were most often affected, these injuries affected employees in all departments (Table 4). 
Table 3. Number of musculoskeletal injuries related to known risk factors by part of body affected and action listed in description of the incident on the OSHA Logs, ${ }^{*}$ 2008-2012

\begin{tabular}{|c|c|c|c|c|c|c|c|c|}
\hline \multirow{2}{*}{$\begin{array}{l}\text { Part of body } \\
\text { affected }\end{array}$} & \multirow{2}{*}{$\begin{array}{l}\text { Number } \\
\text { of } \\
\text { records }\end{array}$} & \multirow{2}{*}{$\begin{array}{c}\text { Any } \\
\text { actions }\end{array}$} & \multicolumn{6}{|c|}{ Type of action } \\
\hline & & & Liftingt & Pushing & Pulling & $\begin{array}{c}\text { Repetitive } \\
\text { motion }\end{array}$ & Bendingt & Reaching† \\
\hline Neck & 1 & 1 & - & 1 & - & - & - & - \\
\hline Chest & 1 & 1 & 1 & - & - & - & - & - \\
\hline Inguinal area & 1 & 1 & - & 1 & - & - & - & - \\
\hline Low back† & 10 & 12 & 7 & 2 & 1 & - & 1 & 1 \\
\hline Shoulder & 4 & 4 & 2 & - & 1 & 1 & - & - \\
\hline Upper arm & 1 & 1 & 1 & - & - & - & - & - \\
\hline Hand/Wrist & 2 & 2 & 1 & - & - & 1 & - & - \\
\hline Finger & 1 & 1 & 一 & 一 & 1 & - & 一 & - \\
\hline Any & 21 & 23 & 12 & 4 & 3 & 2 & 1 & 1 \\
\hline
\end{tabular}

*The Logs included incidents from both shifts. Some of the recorded incidents involved production supervisors and employees who did not work in production areas.

†The total number of injuries is more than the total number of records because two records listed bending or reaching as well as lifting.

Table 4. Number of musculoskeletal injuries related to known risk factors by department and action listed in description of the incident on the OSHA Logs, ${ }^{*}$ 2008-2012

\begin{tabular}{|c|c|c|c|c|c|c|c|c|}
\hline \multirow[t]{2}{*}{ Department $†$} & \multirow{2}{*}{$\begin{array}{l}\text { Number } \\
\text { of } \\
\text { records }\end{array}$} & \multirow{2}{*}{$\begin{array}{c}\text { Any } \\
\text { actions }\end{array}$} & \multicolumn{6}{|c|}{ Type of action } \\
\hline & & & Liftingł & Pushing & Pulling & $\begin{array}{l}\text { Repetitive } \\
\text { motion }\end{array}$ & Bending $\ddagger$ & Reaching \\
\hline $\begin{array}{l}\text { Storeroom and } \\
\text { receiving cooler }\end{array}$ & 2 & 2 & 2 & - & - & - & - & - \\
\hline $\begin{array}{l}\text { Cold and hot } \\
\text { food kitchens }\end{array}$ & 5 & 6 & 2 & 1 & - & 2 & - & 1 \\
\hline Beverage & 4 & 5 & 2 & 1 & 1 & - & 1 & - \\
\hline $\begin{array}{l}\text { Equipment and } \\
\text { sanitation§ }\end{array}$ & 3 & 3 & 3 & - & - & - & - & - \\
\hline Transportationף & 7 & 7 & 3 & 2 & 2 & - & - & - \\
\hline All departments & 21 & 23 & 12 & 4 & 3 & 2 & 1 & 1 \\
\hline
\end{tabular}

*The Logs included incidents from both shifts. Some of the recorded incidents involved production supervisors and employees who did not work in production areas.

†Employee's department; incident might have happened in another location.

†The total number of injuries was more than the total number of records because two records listed bending or reaching as well as lifting.

§Two equipment and sanitation employees' lifting injuries took place in the cold food kitchen.

ПTransportation employees' injuries took place on the facility ramp (3), airport ramp (2), dock (1), and in the beverage department (1).

Over the 5 years of OSHA Logs reviewed, the 21 musculoskeletal injuries related to known ergonomic risk factors accounted for 33\% of total days away from work, job transfer, or job restriction. Using the Bureau of Labor Statistics definition for a full-time employee, these injuries accounted for an equivalent of one full-time employee per year to be away from work, on a job transfer, or on a job restriction (Table 5). 
Table 5. Days away from work, job transfer, or job restriction from musculoskeletal injuries related to known risk factors listed in description of the incident on the OSHA Logs, ${ }^{*}$ 2008-2012

\begin{tabular}{lcccc}
\hline Type of injury & $\begin{array}{c}\text { Number of } \\
\text { recordable } \\
\text { injuries }\end{array}$ & $\begin{array}{c}\text { Away from work, } \\
\text { job transfer, or } \\
\text { job restriction }\end{array}$ & $\begin{array}{c}\text { Away from } \\
\text { work }\end{array}$ & $\begin{array}{c}\text { Job transfer or } \\
\text { job restriction }\end{array}$ \\
\hline $\begin{array}{l}\text { Musculoskeletal injury } \\
\text { possibly related to ergonomic } \\
\text { risk factors }\end{array}$ & 19 & 1,158 days & 198 days & 960 days \\
$\begin{array}{l}\text { Musculoskeletal disorder } \\
\text { attributed to repetitive motion }\end{array}$ & 2 & 43 days & 43 days & - \\
\hline $\begin{array}{l}5 \text {-year totals } \\
\text { Annual average }\end{array}$ & 21 & 1,201 days & 241 days & 960 days \\
\hline $\begin{array}{l}5 \text {-year FTE† equivalent } \\
\text { Annual average FTE equivalent }\end{array}$ & - & 240 days & 48 days & 192 days \\
\hline
\end{tabular}

*The Logs included incidents from both shifts. Some of the recorded incidents involved production supervisors and employees who did not work in production areas.

†FTE = Full-time employee, according to Bureau of Labor Statistics definition, is someone who works 40 hours per week for 50 weeks per year, or 2,000 hours or 250 days per year.

Work activities such as extended reaching, bending at the back, lifting items from various levels, and prolonged standing, whether observed by us or reported by employees, could explain the musculoskeletal symptoms, injuries, and disorders that affected employees throughout the facility. Similar activities were listed in descriptions of the incident on the OSHA Logs. Job-related musculoskeletal disorders make up most of the injuries in food service industries [Cal/OSHA 2003], which includes airline catering. The numbers of symptoms reported by interviewed employees and the injuries listed on the OSHA Logs showed that work-related musculoskeletal disorders and injuries were affecting this airline catering facility as well. Redesigning job tasks and work stations, as well as decreasing the duration of continuous repetitive movements such as rotation to jobs that use different muscle groups are well accepted measures that should reduce employees' risk for musculoskeletal disorders. Additionally, some studies have shown that small increases in break times have decreased symptoms with no significant effect on productivity [Dababneh et al. 2001; Faucett et al. 2007; Galinsky et al. 2007].

We reviewed the company's 36-slide new-hire safety orientation, which included a slide on pushing carts, a slide on lifting and carrying, and slides showing three stretching exercises. We did not evaluate cart pushing policies, which we addressed during our evaluation at the Michigan facility. In that evaluation, we reviewed a report by the company's insurance provider, verified some cart push forces, and agreed with the insurance provider's recommendations [NIOSH 2014b]. Few studies have looked at stretching as a measure to prevent work-related musculoskeletal disorders. When studied, results have been inconclusive, probably for many reasons, such as individual factors (e.g., hypomobility or hypermobility, age), exercise factors (e.g., time of day, duration, repetition, quality), relevance (e.g., job tasks, part of body at risk for injury) [Hess and Hecker 2003], and low use of stretching exercises by employees [Galinsky et al. 2007]. Moreover, the exercises may cause increased musculoskeletal pain [Hess and Hecker 2003]. 
The company's training materials and safety sheets appeared to focus on certain specific risk factors for musculoskeletal disorders and preventive measures that are the responsibility of the employee. For example, a safety sheet on lifting focused on body posture and lifting technique. We did not see training and informational materials about general ergonomic principles that would allow employees to recognize risk factors from any work activity. Many resources are available for improving workplace ergonomics and ergonomic training. California OSHA (Cal/OSHA) Consultation Service, CNA Insurance Companies, Material Handling Industry of America, and NIOSH developed ergonomic guidelines for identifying high risk manual material handling tasks and reducing the associated physical risk factors [Cal/OSHA 2007]. Additionally, the Washington State Department of Labor \& Industries developed an ergonomics program guideline that includes general awareness tips and training to identify musculoskeletal symptoms and risk factors and understand the need to eliminate risk factors, prevent injuries, and keep injuries that occur from becoming disabling [Washington State Department of Labor \& Industries 2008].

A review of participatory ergonomic processes found that training can be tailored to specific workplace risks and hazards or targeted solutions [van Eerd et al. 2010]. However, reaching goals depends on multiple considerations such as creating teams with appropriate members; involving the right people; defining participants' responsibilities; making decisions using group consultations with appropriate roles for employees, employee representatives, and employer representatives; providing ergonomic training; and addressing key factors that could help or hinder the process [van Eerd et al. 2010].

\section{Acute Traumatic Injuries}

Of the 94 injury incidents recorded on the OSHA Logs for 2008-2012, 73 (78\%) were related to acute traumatic incidents (Table 6). Musculoskeletal injuries such as sprain, strain, or pain $(27,36 \%)$ were the most frequent type of injury, followed by laceration $(18,25 \%)$, contusion $(13,18 \%)$, and fracture $(11,15 \%)$. 
Table 6. Number of injuries related to acute traumatic incidents by type of injury and type of action listed in description of the incident on the OSHA Logs, ${ }^{*}$ 2008-2012

\begin{tabular}{|c|c|c|c|c|c|c|c|}
\hline \multirow[t]{2}{*}{ Type of injury } & \multirow{2}{*}{$\begin{array}{c}\text { Any } \\
\text { actiont }\end{array}$} & \multicolumn{6}{|c|}{ Type of action } \\
\hline & & $\begin{array}{l}\text { Struck by or } \\
\text { against, } \\
\text { caught in or } \\
\text { between } \dagger\end{array}$ & $\begin{array}{c}\text { Cut or } \\
\text { punctured } \\
\text { by† }\end{array}$ & $\begin{array}{l}\text { Slip, } \\
\text { trip, or } \\
\text { fall† }\end{array}$ & $\begin{array}{l}\text { Catching or } \\
\text { reaching for } \\
\text { falling } \\
\text { object† }\end{array}$ & Indirect† & $\begin{array}{c}\text { Not } \\
\text { specified }\end{array}$ \\
\hline Musculoskeletalł & 27 & 9 & - & 11 & 4 & 2 & 1 \\
\hline Laceration & 18 & 3 & 14 & 1 & - & - & - \\
\hline Contusion & 13 & 13 & - & - & - & - & - \\
\hline Fracture & 11 & 7 & - & 3 & - & - & 1 \\
\hline Crush§ & 4 & 4 & - & - & - & - & - \\
\hline Punctureף & 2 & - & 2 & - & - & - & - \\
\hline Amputation & 1 & - & 1 & 一 & - & 一 & - \\
\hline All types of injuries & $76^{* *}$ & 36 & 17 & 15 & 4 & 2 & 2 \\
\hline
\end{tabular}

${ }^{*}$ The Logs included incidents from both shifts. Some of the recorded incidents involved production supervisors and employees who did not work in production areas.

†See Table 7 for the specific types of action and agents listed under description of the incident on the OSHA Logs.

$\ddagger$ Sprain, strain, or pain

§lnvolved finger, hand, or toe

Tlnvolved tip of finger

${ }^{* *}$ Three incidents had more than one type of injury.

The most frequent type of action listed in the description of the incident on the OSHA Logs was being struck by or against or caught in or between something $(36,49 \%)$. The "struck" and "caught" actions resulted in 13 contusions, 9 musculoskeletal injuries, 7 fractures, 4 crush injuries, and 3 lacerations.

The second most frequent type of action was "cut by" or "punctured by" (17, or approximately 3 per year). During our employee interviews, 5 of the 66 employees we interviewed said that they had cuts or burns on their hands or arms in the week before our evaluation. Two worked in the hot food kitchen, two in equipment and sanitation, and one in the beverage department. While the review of 5 years of OSHA logs showed 14 laceration injuries ("cut by") and no burn injuries, the five interview reports of cuts or burns the week before our evaluation suggested that these types of injury may be common. We did not evaluate severity of the cuts and burns reported to us; thus, we could not determine if these were minor injuries, which would not have to be recorded on the OSHA Logs.

The third most frequent type of action listed in the description of the incident on the OSHA Logs was 15 incidents of slip, trip, fall, or other mishap when walking. In response to the open-ended question about health and safety concerns, four employees reported floors 
slippery with water, ice, or food. Of the five OSHA-Log recorded slips that ended with a fall, two were caused by food on the floor and one by water under a mat, which were similar to the concerns reported during the employee interviews. Thus, in the presence of floor hazards, the use of slip-resistant shoes alone ( $99 \%$ of interviewed employees reported wearing them) did not prevent these injuries.

Table 7 shows the agents listed in the description of the incident on the OSHA Logs. Falling carts were responsible for at least 9 injuries ( 6 struck by and 3 catching or reaching for). Agents that might have contributed to incidents were not specified for at least 14 incidents. Injuries recorded on the OSHA Logs happened in all departments (Table 8).

Table 7. Number of acute traumatic incidents by types of action and agents listed under description of the incident on the OSHA Logs, ${ }^{*}$ 2008-2012

\begin{tabular}{|c|c|c|}
\hline Type of action & Number & Agents $\dagger$ \\
\hline Struck by & 21 & $\begin{array}{l}\text { Falling object, such as cart (6), boxes, cart drawer, } \\
\text { dock plate, employee } \\
\text { Door of truck, cart, dish machine } \\
\text { Other object, such as cart, wagon, box, crate milk, dry ice } \\
\text { bin lid, floor jack }\end{array}$ \\
\hline Struck against & 5 & Steering wheel, truck door, wall, oven rack \\
\hline Caught in or between & 10 & $\begin{array}{l}\text { Cart, door, gate rack, elevator shaft, truck door, jack and } \\
\text { pole, latch }\end{array}$ \\
\hline Cut or punctured by & 15 & $\begin{array}{l}\text { Sharp tools or instruments, such as knife (4), mandolin, } \\
\text { slicer, drill, aluminum foil box blade } \\
\text { Broken dishes (4) } \\
\text { Oven cover }\end{array}$ \\
\hline $\begin{array}{l}\text { Slip, trip, or fall or } \\
\text { other mishaps while } \\
\text { walking }\end{array}$ & 14 & Food on floor, water under mat, floor jack \\
\hline $\begin{array}{l}\text { Catching or reaching } \\
\text { for falling object }\end{array}$ & 4 & Falling carts (3), falling box \\
\hline Indirect & 2 & $\begin{array}{l}\text { In a motor vehicle that struck something, cart jerked when } \\
\text { wheel caught by something }\end{array}$ \\
\hline
\end{tabular}

${ }^{*}$ The Logs included incidents from both shifts. Some of the recorded incidents involved production supervisors and employees who did not work in production areas.

tWhen specified. Number of incidents in parentheses when involved in more than one incident. Agents were not specified for 14 incidents. 
Table 8. Number of injuries related to acute traumatic incidents by department and action listed in description of the incident on the OSHA Logs, ${ }^{*}$ 2008-2012

\begin{tabular}{|c|c|c|c|c|c|c|c|}
\hline \multirow[t]{2}{*}{ Department $†$} & \multirow{2}{*}{$\begin{array}{l}\text { Any } \\
\text { action }\end{array}$} & \multicolumn{6}{|c|}{ Type of action } \\
\hline & & $\begin{array}{l}\text { Struck by or } \\
\text { against, } \\
\text { caught in or } \\
\text { between } \ddagger\end{array}$ & $\begin{array}{l}\text { Cut or } \\
\text { punctured } \\
\text { by }\end{array}$ & $\begin{array}{l}\text { Slip, } \\
\text { trip, or } \\
\text { fall }\end{array}$ & $\begin{array}{l}\text { Catching or } \\
\text { reaching } \\
\text { for } \\
\text { falling } \\
\text { objectł }\end{array}$ & Indirectł & $\begin{array}{c}\text { Not } \\
\text { specified }\end{array}$ \\
\hline $\begin{array}{l}\text { Storeroom and } \\
\text { receiving cooler }\end{array}$ & 4 & 2 & - & 1 & 1 & - & - \\
\hline Cold food kitchen & 13 & 4 & 6 & 3 & - & - & - \\
\hline Hot food kitchen & 5 & & 3 & 2 & - & - & - \\
\hline Beverage & 12 & 6 & 4 & 1 & - & - & 1 \\
\hline $\begin{array}{l}\text { Equipment and } \\
\text { sanitation }\end{array}$ & 12 & 7 & 1 & 4 & - & - & - \\
\hline Transport & 21 & 13 & - & 2 & 3 & 2 & 1 \\
\hline Other§ & 6 & 4 & 1 & 1 & 一 & 一 & 一 \\
\hline All departments & 73 & 36 & 15 & 14 & 4 & 2 & 2 \\
\hline
\end{tabular}

*The Logs included incidents from both shifts. Some of the recorded incidents involved production supervisors and employees who did not work in production areas.

†Employee's department; incident might have happened in another location

$\ddagger$ See Table 7 for the specific types of action and agents listed under description of the incident on the OSHA Logs.

$\S$ Nonproduction employees, e.g., supervisor or cafeteria employee

On the OSHA Logs, the 73 injuries related to acute traumatic incidents accounted for $67 \%$ of the total days away from work, job transfer, or job restriction. Using the Bureau of Labor Statistics definition for a full-time employee, these injuries caused the equivalent of two full-time employees per year to be away from work, on a job transfer, or on a job restriction (Table 9).

Table 9. Days away from work, job transfer, or job restriction related to injuries caused by acute traumatic incidents recorded on the OSHA Logs, ${ }^{*}$ 2008-2012

\begin{tabular}{lcccc}
\hline $\begin{array}{l}\text { Injuries caused by acute } \\
\text { traumatic incidents }\end{array}$ & $\begin{array}{c}\text { Number of } \\
\text { recordable } \\
\text { injuries }\end{array}$ & $\begin{array}{c}\text { Away from work, } \\
\text { job transfer, or } \\
\text { job restriction }\end{array}$ & $\begin{array}{c}\text { Away from } \\
\text { work }\end{array}$ & $\begin{array}{c}\text { Job transfer or } \\
\text { job restriction }\end{array}$ \\
\hline 5-year totals & 73 & 2,468 days & 751 days & 1,717 days \\
Annual average & 14.6 & 493.6 days & 150.2 days & 343.4 days \\
\hline 5-year FTE† equivalent & & 9.9 FTEs & 3.0 FTEs & 6.9 FTEs \\
$\begin{array}{l}\text { Annual average FTE } \\
\text { equivalent }\end{array}$ & & 2.0 FTEs & 0.6 FTE & 1.4 FTEs \\
\hline
\end{tabular}

*The Logs included incidents from both shifts. Some of the recorded incidents involved production supervisors and employees who did not work in production areas.

†FTE = Full-time employee, according to Bureau of Labor Statistics definition, is someone who works 40 hours per week for 50 weeks per year, or 2,000 hours or 250 days per year. 
When combining possible work-related musculoskeletal disorders and acute traumatic injuries, the incidence rates of injuries recorded on the OSHA Logs ranged from 5.0 to 5.8 injury cases per 100 full-time employees from 2008-2012 (Table 10); the facility's rate ranged from 0.5 to 1.3 times the rate found by the special food services industry [BLS 2015], which includes airline catering facilities. The facility's rates in the last 3 years of our review were basically the same as industry rates.

Table 10. Incidence rates for all injuries recorded on the OSHA Logs, 2008-2012, ${ }^{*}$ compared with rates in the special food services industry (NAICS 7223)

\begin{tabular}{ccccc}
\hline Year & $\begin{array}{c}\text { Number of facility's } \\
\text { recordable injuries }\end{array}$ & $\begin{array}{c}\text { Facility's } \\
\text { total recordable } \\
\text { injury cases } \\
\text { per 100 FTEs }\end{array}$ & $\begin{array}{c}\text { Special food } \\
\text { services industry } \\
\text { injury cases } \\
\text { per 100 FTEs }\end{array}$ & $\begin{array}{c}\text { Company to } \\
\text { industry } \\
\text { rate ratio }\end{array}$ \\
\hline 2008 & 18 & 5.2 & 9.5 & 0.5 \\
2009 & 18 & 5.5 & 4.2 & 1.3 \\
2010 & 20 & 5.8 & 5.4 & 1.1 \\
2011 & 19 & 5.1 & 5.0 & 1.0 \\
2012 & 19 & 5.0 & 5.7 & 0.9 \\
\hline
\end{tabular}

*The Logs included incidents from both shifts. Some of the recorded incidents involved production supervisors and employees who did not work in production areas.

†FTE = Full-time employee, according to Bureau of Labor Statistics definition, is someone who works 40 hours per week for 50 weeks per year, or 2,000 hours or 250 days per year.

$\ddagger$ Bureau of Labor Statistics annual tables of incidence rates of nonfatal occupational injuries and illnesses by industry and case types, 2008-2012

The OSHA Logs show that injury rates at the facility are similar to the overall special food services industry rates. This comparison can be useful when evaluating injury trends over time and a company's direct and indirect costs, such as medical care, temporary and permanent disability, lost work time, and replacing injured personnel. However, these costs do not measure the burden on injured employees and their families.

Reports of ergonomic evaluations by the company's insurance carrier gave recommendations for preventing acute traumatic injuries, some of which appeared in company-developed standard operating procedures, trainings, and informational materials. Additional measures could be taken to reduce acute traumatic injuries. Summarizing OSHA Log data can be useful in identifying risk factors to target for improving workplace safety. The OSHA Logs can also help determine priorities. For example, severe injuries can be identified by type of injury and days away from work, job transfer, or job restriction; common injuries can be identified by frequencies of types of injury; and common causes can be identified by frequencies of actions (e.g., struck by) and agents (e.g., falling carts) listed in the description of the incident. Descriptions of actions and agents that contribute to injuries can suggest preventive measures (e.g., falling objects, floor hazards). However, missing information on the Logs (e.g., lack of action or agent in the description of the incident) leads to unidentified causes and gives misleadingly low numbers that would affect decisions about priorities. 
We reviewed the company's standard operating procedures and training materials about safety hazards that can cause acute traumatic injuries. Our findings and discussion on these documents are covered in the section on language, communication, and training below.

\section{Exposure to Cold Environments}

Temperatures that we measured in all five coolers were approximately $40^{\circ} \mathrm{F}$, the temperature required by food safety standards. The air temperature was maintained by recirculating roofmounted refrigerator units (heat pumps) located on the roof of each room. No outdoor air was introduced into the coolers by the heat pumps. Each cooler had a thermometer that displayed the temperature inside the cooler. The temperature was also displayed outside the room. Temperatures were documented daily for both shifts and the thermometers were checked monthly for accuracy against a calibrated thermometer.

At the time of our evaluation, 53 of the 56 first-shift cold food kitchen employees were food preparers. Employees working in the production coolers of the cold food kitchen were potentially exposed to cold temperatures and drafts from vents and fans blowing directly on them during the majority of their shift. We estimated the activity level for most employees working in the production coolers as light to moderate, depending on the job tasks for the day. The facility provided mandatory PPE to protect the food from contamination (e.g., lab coat, hairnet, plastic sleeve guards, plastic or polyvinyl chloride gloves, and apron) and optional PPE for warmth (e.g., coat, hat, and liner gloves). Employees also reported wearing additional personal clothing for warmth. Employees outside the cold food kitchen were exposed to indoor cold temperatures when entering coolers to stock and retrieve items from the storage and thaw area coolers and to move carts into and out of the holding cooler. Transportation department employees were also exposed to outdoor cold temperatures.

Table 11 describes the number of employees we observed in the different coolers during our visit and the air velocity measurements taken during our visit. All room air velocities were below the American Conference of Governmental Industrial Hygienists (ACGIH®) cold stress threshold limit value (TLV®) guideline of 200 feet per minute for job sites inside refrigerated rooms [ACGIH 2015].

Table 11. Air velocities measured in coolers at chest height on January 15 and 16, 2013

\begin{tabular}{lcccc}
\hline $\begin{array}{l}\text { Cooler } \\
\text { number }\end{array}$ & Departments & Description & $\begin{array}{c}\text { Approximate number } \\
\text { of employees }\end{array}$ & $\begin{array}{c}\text { Air velocity, } \\
\text { feet per minute }\end{array}$ \\
\hline 1 & $\begin{array}{c}\text { Storeroom and } \\
\text { receiving cooler } \\
\text { Cold food kitchen }\end{array}$ & Storage cooler & $0-1$ & $0-60$ \\
2 & $\begin{array}{c}\text { Production cooler } \\
\text { in cold food prep } \\
\text { Thaw area }\end{array}$ & $7-12$ & $0-125$ \\
3 & Hot food kitchen & $\begin{array}{c}\text { Production cooler } \\
\text { in cold food prep } \\
\text { Holding area }\end{array}$ & $1-2$ & 0 \\
5 & Cold food kitchen & $2-5$ & 0 \\
& $\begin{array}{c}\text { Cold food kitchen } \\
\text { Transportation }\end{array}$ & $1-3$ & $0-50$ \\
\hline
\end{tabular}


We reviewed daily cooler temperature records obtained from the company for 2 months in 2012. Temperatures recorded by the company were fairly uniform between the months and work shifts, at approximately $40^{\circ} \mathrm{F}$, which is required by food safety standards, and similar to the measurements we took (Table 12).

Table 12. Cooler daily temperature records provided by the company, 2012

\begin{tabular}{|c|c|c|c|c|c|c|c|}
\hline \multirow[t]{2}{*}{ Month, Year } & \multirow[t]{2}{*}{ Shift } & & \multicolumn{5}{|c|}{ Temperature, ${ }^{\circ} \mathrm{F}$} \\
\hline & & & $\begin{array}{c}\text { Cooler } \\
\# 1\end{array}$ & $\begin{array}{c}\text { Cooler } \\
\# 2\end{array}$ & $\begin{array}{c}\text { Cooler } \\
\# 3\end{array}$ & $\begin{array}{c}\text { Cooler } \\
\# 4\end{array}$ & $\begin{array}{c}\text { Cooler } \\
\# 5\end{array}$ \\
\hline \multirow[t]{6}{*}{ September 2012} & Day & Average & 40.0 & 39.6 & 39.9 & 39.9 & 39.4 \\
\hline & & Minimum & 39.0 & 36.0 & 38.0 & 39.0 & 37.0 \\
\hline & & Maximum & 40.0 & 40.0 & 41.0 & 40.0 & 40.0 \\
\hline & Night & Average & 40.0 & 39.4 & 39.7 & 39.6 & 39.2 \\
\hline & & Minimum & 39.0 & 37.0 & 37.0 & 38.0 & 36.0 \\
\hline & & Maximum & 41.0 & 41.0 & 42.0 & 41.0 & 40.0 \\
\hline \multirow[t]{6}{*}{ December 2012} & Day & Average & 39.9 & 40.0 & 40.2 & 39.0 & 40.2 \\
\hline & & Minimum & 39.0 & 38.0 & 39.0 & 37.0 & 39.0 \\
\hline & & Maximum & 41.0 & 41.0 & 41.0 & 40.0 & 41.0 \\
\hline & Night & Average & 40.0 & 40.2 & 40.1 & 37.9 & 40.0 \\
\hline & & Minimum & 40.0 & 39.0 & 38.0 & 32.0 & 38.0 \\
\hline & & Maximum & 40.0 & 42.0 & 42.0 & 41.0 & 41.0 \\
\hline
\end{tabular}

Almost half (47\%) of the 66 employees we interviewed reported that they worked in the cold (Table 13). Most (78\%) of them worked in the cold food kitchen. However, employees from all departments except the hot food kitchen reported working in the cold. Transportation employees reported being exposed to cold temperatures in winter because some trucks did not have heat. Nearly all $(90 \%)$ of the employees who reported working in the cold also reported that they wore a coat. Nineteen $(29 \%)$ of the interviewed employees reported that they felt discomfort working in cold temperatures, particularly in the freezer or coolers; several mentioned that their feet and hands got the coldest while working in these locations. Some employees reported cold fingers but felt that using gloves would impair their dexterity. Sixteen (24\%) of the interviewed employees reported that they had become ill from exposure to extreme temperatures at work but, for this interview question, we did not differentiate extreme cold from extreme heat. Nine of the sixteen employees who answered "yes" to this question said that they worked in cold temperatures. However, six of them also reported that they worked in hot temperatures. 
Table 13. Interviewed employees by department who reported work in the cold, experiencing discomfort working in cold temperatures, and becoming sick because of extreme temperatures at work, January 2013

\begin{tabular}{lcccc}
\hline Department & $\begin{array}{c}\text { Number of } \\
\text { interviewed } \\
\text { employees }\end{array}$ & \multicolumn{2}{c}{ Number (\%) of interviewed employees who reported: } \\
\cline { 3 - 5 } & & $\begin{array}{c}\text { Work in } \\
\text { the cold }\end{array}$ & $\begin{array}{c}\text { Discomfort working } \\
\text { in cold } \\
\text { temperatures }\end{array}$ & $\begin{array}{c}\text { Ever becoming sick } \\
\text { because of extreme } \\
\text { temperatures at work }\end{array}$ \\
\hline $\begin{array}{l}\text { Storeroom and } \\
\text { receiving cooler }\end{array}$ & 9 & $4(44)$ & $4(44)$ & $2(22)$ \\
$\begin{array}{l}\text { Cold food kitchen } \\
\text { Hot food kitchen }\end{array}$ & 18 & $14(78)$ & $7(39)$ & $2(11)$ \\
$\begin{array}{l}\text { Beverage } \\
\text { Equipment and }\end{array}$ & 8 & - & $1(13)$ & $1(13)$ \\
sanitation & 11 & $2(18)$ & $2(18)$ & $3(30)$ \\
$\begin{array}{l}\text { Transportation } \\
\text { All departments }\end{array}$ & 10 & $3(30)$ & $4(40)$ & $4(40)$ \\
\hline
\end{tabular}

*In two departments (hot food kitchen and equipment and sanitation), the number reporting discomfort from cold was larger than the number reporting work in the cold. This could be explained by the following: (1) the two questions about "work in the cold" and "discomfort working in cold temperatures" were asked in different parts of the interview; (2) hot food employees entered the thaw area cooler and freezer as needed; and (3) some cold exposures might have been related to outdoor temperatures.

†For this interview question, we did not differentiate extreme cold from extreme heat. Nine of these reports came from employees who reported work in cold temperatures, six of whom also reported work in hot temperatures.

Employee reports of discomfort while working in cold environments could be explained by the temperatures we found in the freezers and coolers, where employees spent varying amounts of work time. These findings indicate that preventive measures against cold exposure might not be adequate. Studies have shown that cold indoor work in the food industry often involves light physical activity and repetitive movements [Mäkinen and Hassi 2009], similar to what we found at this facility. Mild cold exposures can cause unpleasant sensations and temperature discomfort, which can distract from the performance of tasks requiring concentration and vigilance and may increase the risk of traumatic incidents and injuries. Cooling of body tissue can reduce physical and mental performance, which may contribute to the risk of potentially traumatic incidents and injuries [Mäkinen and Hassi 2009]. Additionally, cold indoor work has been associated with musculoskeletal symptoms and disorders as well as the aggravation of chronic medical conditions [Piedrahita 2008; Mäkinen and Hassi 2009]. Measures to improve employees' general heat balance include reducing their exposure to drafts, keeping cold goods away from work stations, and adding clothing to protect from draft, moisture, and water. Underwear, insulating middle layers, and the outer layer should be integrated into a functional and protective system. Headgear and footwear should be insulated to preserve warmth. The hands and fingers are particularly sensitive to cold. Gloves improve protection but affect dexterity. Thin gloves may be sufficient but additional measures, such as insulated handles on tools and equipment, spot heating, and routine breaks for recovery and rewarming, may be needed [Dahlström et al. 
2011]. ACGIH recommends that if fine work is to be performed with bare hands for more than 10-20 minutes in an environment below $60.8^{\circ} \mathrm{F}$, special provisions should be established for keeping the employee's hands warm [ACGIH 2015]. The chapter on cold environment and cold work in the International Labor Organization Encyclopaedia of Occupational Health \& Safety [Dahlström et al. 2011] includes information about conditioning programs for cold store workers, the selection of protective clothing, and other protective measures.

\section{Exposure to Hot Environments}

Although outdoor temperatures were low during our visit, the potential for work in hot conditions exists, particularly during the summer months. Nearly half (49\%) of interviewed employees reported that they felt discomfort working in hot temperatures. When asked to elaborate about the cause in an open-ended question, the most frequently reported responses were lack of air conditioning, having too few fans, and weather during summer months. Transportation department employees reported being exposed to heat in summer because some delivery trucks did not have air conditioning. As reported in Table 13 above, 16 (24\%) of the interviewed employees reported that they had become ill from exposure to extreme temperatures at work. For this interview question, we did not differentiate extreme cold from extreme heat. When we asked them to describe their symptoms, three employees reported symptoms more likely to be related to heat exposure than to cold exposure, such as dizziness, fast heartbeat, stomach cramps, and nausea. These employees worked in beverage, equipment and sanitation, and the hot food kitchen. We discussed work in hot environments and made recommendations about exposure to hot environments in the report of our earlier evaluation at the company's airline catering facility in Michigan [NIOSH 2014b].

\section{Dehydration and Drinking Water}

Performance can be affected by dehydration from sweat losses and fluid restriction or unavailability [Cheuvront and Kenefick 2014]. Work factors, such as physical exertion, hot environments, and cold environments can contribute to sweat losses. In hot environments and during physical exertion, increased sweat production is part of the evaporative mechanism to cool the body [Kenney 2011]. In cold environments, protective clothing can cause increased sweat production because of its heat-retaining properties or by adding to an employee's workload because of its weight [Dahlström et al. 2011]. Thus, employees who worked in hot environments, performed tasks that required physical exertion, or wore protective clothing with heat-retaining properties might have been at risk for increased sweat loss.

Twenty-five (38\%) of the interviewed employees reported that they did not have enough water to drink during their shift. Employees reported that they were permitted to drink water only on breaks, drinking water was not available in most work areas, the drinking fountain in the storeroom had been replaced with an eye wash, the water fountains located in the receiving area and the cafeteria did not meet the needs of employees in departments that did not have a drinking fountain, and open bottles of water were prohibited in work areas. Thirst is not a good indicator of dehydration and may be satisfied well before total body water is fully restored even when dehydration is substantial [Cheuvront and Kenefick 2014]. Employee reports of not having enough water to drink suggest that some employees were 
thirsty because of dehydration; however, additional employees might have been dehydrated without feeling thirsty.

Dehydration can cause unpleasant symptoms such as dry mouth, thirst, headache, tiredness, and decreased alertness. These and other symptoms may be distracting and affect performance. Additionally, tasks that have an aerobic or endurance component, such as day-long manual labor, appear to be significantly impaired by dehydration [Cheuvront and Kenefick 2014]. Thus, the lack of access to drinking water in work areas led to involuntary fluid restriction, which could increase the risk of dehydration that could affect employees' work performance.

\section{Carbon Dioxide}

We observed the use of dry ice, a source of $\mathrm{CO}_{2}$ in air, not only in the coolers and prep areas, but also throughout the facility. Although the employer had prohibited the use of dry ice in coolers, we saw dry ice in drawers on top of ice cream and juice containers in coolers 4 and 5, even though these were unventilated spaces. The cooler doors and interiors did not have signs warning employees about the hazards of dry ice or that its use was prohibited in coolers. Our grab sample results showed that $\mathrm{CO}_{2}$ concentrations in the air were elevated in the coolers and in prep areas 1 and 2 (Table 14). The highest $\mathrm{CO}_{2}$ concentrations were found in coolers 3 and 5, even though dry ice was not in use in these coolers when we took our measurements (Table 14). Grab sample results cannot be used reliably to estimate an employee's personal exposure to $\mathrm{CO}_{2}$ or to compare with the occupational exposure limits (OELs). However, these results indicated a possibility that, if dry ice is used in unventilated coolers, $\mathrm{CO}_{2}$ concentrations could build up and remain high; employees working in coolers with dry ice for extended time periods could be exposed to $\mathrm{CO}_{2}$ levels above the OSHA permissible exposure limit (PEL) and NIOSH recommended exposure limit (REL) of $5,000 \mathrm{ppm}$ as a time-weighted average over the work shift. Because dry ice was not being used at the time of sample collection in the coolers, we could not determine whether $\mathrm{CO}_{2}$ concentrations in the coolers would be able to reach the NIOSH short-term exposure limit (STEL) of 30,000 ppm.

Employees had been trained about the hazards of $\mathrm{CO}_{2}$ in Spanish and English, and the hazard communication training material on $\mathrm{CO}_{2}$ was available in Spanish. However, language, communication, and training issues might have affected training effectiveness (see the section on language, communication, and training later in this report). We did not evaluate whether other factors, such as the role of supervisors, might have contributed to the practice of using dry ice where prohibited.

A ventilation outdoor air rate of 10 cubic feet per minute per occupant is recommended inside a freezer or refrigerated area $\left(<50^{\circ} \mathrm{F}\right)$ to provide indoor air quality that is acceptable to human occupants and that minimizes adverse health effects [ANSI/ASHRAE 2013]. This means that, at this facility, an ideal ventilation outdoor air rate would need to supply a minimum of 120 cubic feet per minute, if 12 employees work inside the cooler during most of their shift. If dry ice use continues inside coolers, the ventilation outdoor air rate would need to be higher. Employee exposures to $\mathrm{CO}_{2}$ should be monitored to ensure they are below OELs. 
Table 14. Air concentrations of carbon dioxide $\left(\mathrm{CO}_{2}\right)$ in air from grab samples, January 15 and 16, 2013

\begin{tabular}{|c|c|c|c|c|}
\hline \multirow{2}{*}{$\begin{array}{l}\text { Sample } \\
\text { Location }\end{array}$} & \multirow[t]{2}{*}{ Description } & \multirow{2}{*}{$\begin{array}{c}\text { Dry ice used } \\
\text { during sampling? }\end{array}$} & \multicolumn{2}{|c|}{$\mathrm{CO}_{2}$ concentration, $\mathrm{ppm}$} \\
\hline & & & Q-track & Dräger tubes \\
\hline Cooler 1 & $\begin{array}{l}\text { Storage cooler in storeroom } \\
\text { and receiving cooler }\end{array}$ & No & 1,320 & - \\
\hline Cooler 2 & $\begin{array}{l}\text { Production cooler in } \\
\text { cold food kitchen }\end{array}$ & No & 1,882 & - \\
\hline Cooler 3 & Thaw area in hot food kitchen & $\begin{array}{l}\text { No } \\
\text { No }\end{array}$ & $\begin{array}{c}>3,000 \\
-\end{array}$ & $\begin{array}{l}3,000 \\
9,000\end{array}$ \\
\hline Cooler 4 & $\begin{array}{l}\text { Production cooler in } \\
\text { cold food kitchen }\end{array}$ & No & $2,353-2,430$ & 3,200 \\
\hline Cooler 5 & $\begin{array}{l}\text { Holding area from cold food } \\
\text { kitchen to transportation }\end{array}$ & $\begin{array}{l}\text { No } \\
\text { No } \\
\text { No }\end{array}$ & $\begin{array}{c}-\overline{3,000} \\
-\end{array}$ & $\begin{array}{c}7,000 \\
>2,000 \\
2,000\end{array}$ \\
\hline Prep area 1 & Near cooler 4 & Yes & - & 3,000 \\
\hline Prep area 2 & Near silverware rolling & Yes & - & 2,000 \\
\hline Prep area 3 & Preparing breakfast trays & Yes & - & 1,000 \\
\hline Loading dock & Dry ice loader & Yes & - & 500 \\
\hline Office area & Conference room & No & 893-911 & - \\
\hline $\begin{array}{l}\text { OSHA PEL* }(8 \\
\text { NIOSH STEL }\end{array}$ & TWA) and NIOSH REL† (10-r & NA) & $\begin{array}{c}5,000 \\
30,000 \\
\end{array}$ & $\begin{array}{c}5,000 \\
30,000 \\
\end{array}$ \\
\hline
\end{tabular}

${ }^{*} \mathrm{PEL}=$ permissible exposure limit as an 8-hour time-weighted average (TWA)

†REL = recommended exposure limit for up to a 10-hour TWA

$\ddagger S T E L$ = short-term exposure limit

\section{Carbon Monoxide}

We did not detect CO (limit of detection was $1 \mathrm{ppm}$ ) in the dock area, which suggested that truck exhaust was negligible in this work area. We noted that docks were sealed and delivery trucks were parked at a distance while idling during winter months. Employees in the area did not express concerns about truck exhaust. Our observations suggest that no changes need to be made to the docks at this facility. If concerns about truck exhaust arise in the future, we suggest that the employer assess employees' exposures to truck exhaust because diesel exhaust is a probable human and occupational carcinogen [NIOSH 1988; International Agency for Research on Cancer 1989].

\section{Job Stress and Psychosocial Factors}

Psychosocial factors are those aspects of the design and management of work (e.g., scheduling, job demands, task complexity) as well as its social and organizational contexts (e.g., interpersonal relationships, role requirements, organizational climate) that have the potential for causing physical or psychological harm to employees [Cox and Griffiths 2005]. Many psychosocial factors are associated with job stress, or the harmful physical and emotional responses that occur when the requirements of a job are a poor match to the capabilities, resources, or needs of the worker [NIOSH 2009]. 
We asked the interviewed employees to rate their level of job stress over the past week on a scale from 0 (as good as it can be) to 10 (as bad as it can be) [Clark et al. 2011]. Sixty-six employees answered this question, with the average response being 5.6. Figure 1 shows the distribution of responses to this question. Twenty percent of scores were $0-3$ (low job stress), 42\% were 4-6 (moderate job stress), and 38\% were 7-10 (high job stress) [Clark et al. 2011]. The job stress scores reported at this facility were greater than those reported at the company's facility we evaluated in Michigan, where $49 \%$ of employees reported low job stress, and the average job stress score was $4.2(\mathrm{~N}=53)$ [NIOSH 2014b].

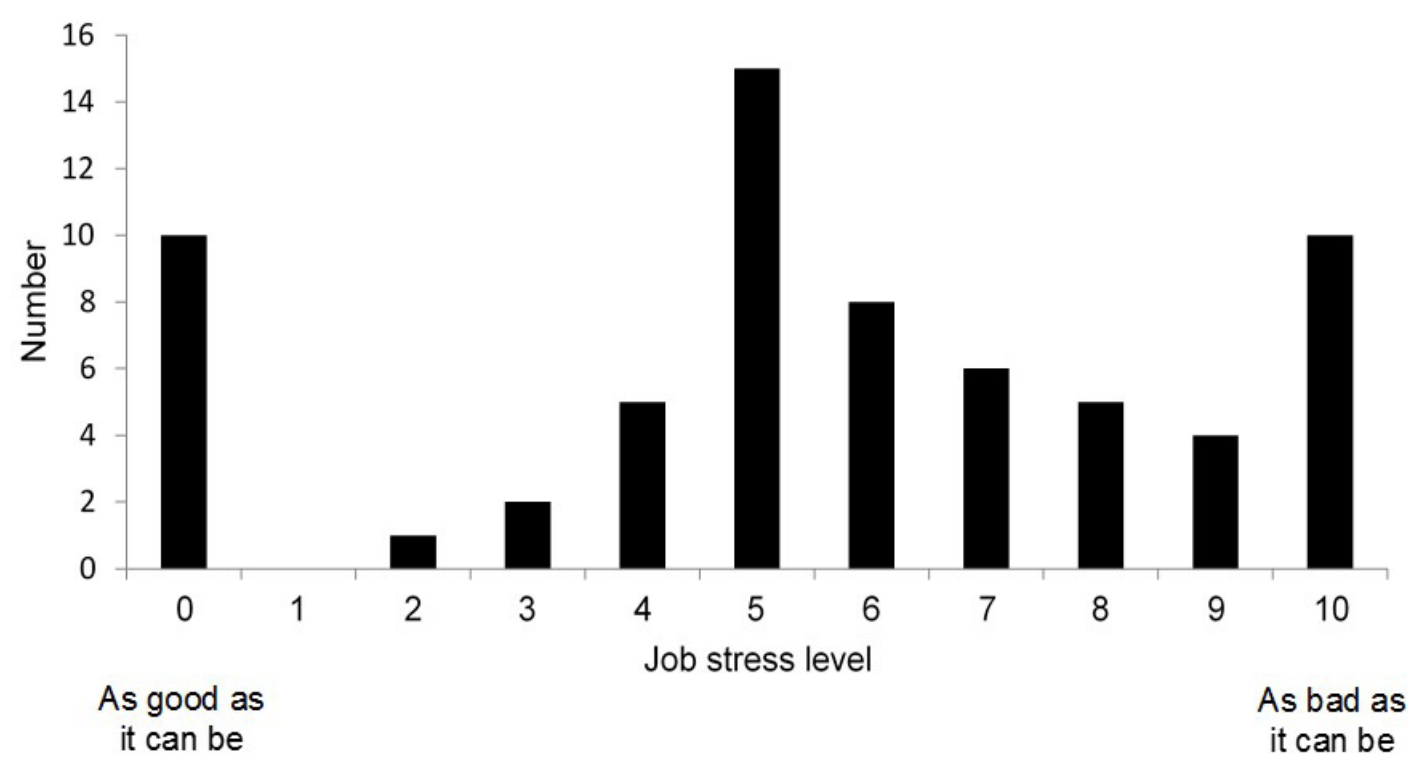

Figure 1. Reported job stress level over the past week $(n=66)$.

We also asked the interviewed employees an open-ended question regarding what factors contributed to their perception of job stress. Fifty-three (80\%) employees reported one or more job stressor(s). Job stressors reported by five or more employees are listed in Table 15. Employees could report more than one job stressor. The most commonly reported job stressors were time pressure, high workload, limited access to resources, and having to work more to make up for the shortcomings of coworkers. These were also the most commonly reported job stressors at the company's facility in Michigan [NIOSH 2014b]. 
Table 15. Reported job stressors among employees $(n=66)$,

January 2013

\begin{tabular}{lc}
\hline Job stressor & $\begin{array}{c}\text { Number of } \\
\text { employees (\%) }\end{array}$ \\
\hline Time pressure (e.g., being rushed) & $24(36)$ \\
High workload & $14(21)$ \\
Limited access to resources & $13(20)$ \\
No reported job stressor(s) & $13(20)$ \\
Making up for shortcomings of coworkers & $11(17)$ \\
Having to work overtime & $8(12)$ \\
Understaffed & $8(12)$ \\
\hline
\end{tabular}

We asked several questions related to interpersonal relationships at work. Sixty-one (94\%) of 66 interviewed employees reported that they never or rarely argued with their coworkers. Forty-two $(67 \%)$ reported that they believed their coworkers help and support each other. Nearly all (97\%) employees reported that their supervisor never or rarely yelled at them; however, 7 employees $(11 \%)$ reported that they had been cursed at by their supervisor. Of the 62 interviewed employees who answered the question on reporting concerns about safety and health matters to their supervisor, $8(13 \%)$ reported that they did not feel safe to do so. Of the 66 interviewed employees, $10(15 \%)$ employees reported that they felt discriminated against at work due to their race, ethnicity, color, or national origin. We did not ask questions about whether the perceived discrimination came from supervisors or coworkers. We also did not ask questions to determine whether these perceptions might have been related to language differences or other communication problems.

Research supports a strong association between job stress, psychosocial factors, and workrelated musculoskeletal disorders [NIOSH 1997; Warren 2001]. Job stress may cause chronic increased muscle tension, thus making soft tissues more susceptible to the effects of physical stressors. Job stress may also raise awareness of musculoskeletal disorder symptoms and affect reporting behavior [NIOSH 1997]. For example, the interactive effects of adverse psychosocial factors (e.g., high workload, low social support, and low job control) and physical stressors are related to the development of musculoskeletal pain in the lower back [De Beeck and Hermans 2000; World Health Organization 2010]. A combination of ergonomic, job design (e.g., rotation of tasks), and psychosocial interventions may result in a decrease in job stress and musculoskeletal pain.

\section{Language, Communication, and Training}

The sample of employees we interviewed was diverse in terms of ethnicity and primary language. They came from 18 different countries of origin, with the most common being the Dominican Republic (32\%) and Colombia (14\%). Most employees (71\%) reported that Spanish was their primary language, while only about $20 \%$ reported English as their primary language. Other primary languages included Indonesian, Italian, Romanian, Tibetan, and Vietnamese. Thirty-three employees (50\%) reported that they spoke at least some English as 
a secondary language. We were unable to interview one selected employee because he did not speak English or Spanish.

Most ( $80 \%)$ of the interviewed employees reported having no difficulty communicating with others at work (Table 16$)$. Most (83\%) reported that they were trained in their primary language and that training materials and health and safety information were available in their primary language (Table 16). Additionally, most (92\%) did not feel pressure to learn English or another language. However, 17\% reported that training, training materials, and health and safety information were not in their primary language, and $20 \%$ reported problems communicating with others because they spoke a different language. These findings suggest that, for some employees, language was a barrier to effective training and communication regarding workplace safety and health. NIOSH has long recognized the need for labels and warning signs to be available in the predominant language of non-English-reading employees and the need to inform those who cannot read the labels and signs because of literacy levels or language [NIOSH 1976]. An OSHA memorandum to OSHA regional administrators about employers' obligations for employee training states that training should be in a language and vocabulary that employees understand, which would be expected when communicating work instructions and other workplace information to employees who have a limited vocabulary or whose primary language is not English [OSHA 2010].

Table 16. Employee responses to interview questions about language, January 2013

\begin{tabular}{lcc}
\hline Interview question & $\begin{array}{c}\text { Number } \\
\text { answering } \\
\text { question }\end{array}$ & $\begin{array}{c}\text { Number (\%) } \\
\text { of "yes" } \\
\text { responses }\end{array}$ \\
\hline $\begin{array}{l}\text { At work, do you have problems communicating with others } \\
\text { because they speak a different language? }\end{array}$ & 66 & $13(20)$ \\
$\begin{array}{l}\text { Were you trained for your job in your primary language? } \\
\text { Are job training materials and health and safety information } \\
\text { available to you in your primary language? }\end{array}$ & 63 & $52(83)$ \\
$\begin{array}{l}\text { At work, have you felt pressure to learn English or another } \\
\text { language? }\end{array}$ & 63 & $52(83)$ \\
\hline
\end{tabular}

We reviewed the new-hire orientation, standard operating procedures, and training and informational materials that the company developed to inform employees about workplace hazards. Most of the materials relied heavily on the written word, often in the form of lists of bullets, to convey a lot of complex information. Standard operating procedures were mostly one or two pages long. A 14-page training module that covered hazard analysis and control, government compliance policies and procedures, PPE, housekeeping tips, and safe behavior also contained checklists for rating good practices. A 36-slide new hire orientation had colorful background graphics that were not relevant to the training, had few photographs, and relied heavily on the written word. One of the informational materials about preventing slip hazards was in poster format with photographs of unsafe and good practices, but the safety message was not immediately obvious. The football player analogy in a poster about PPE might be appropriate for an American-born workforce; its relevance to a workforce of 
multinational origin is unclear. These findings suggest that communication barriers other than language, such as unclear, distracting, and culturally inappropriate visual images and written materials, could have a negative impact on safety and health.

Training is most effective when adult learning principles and learning styles are taken into account [United Nations Environment Programme 2015]. The only document we reviewed that appeared to have been developed according to the principles of adult learning and the consideration of learning styles was the company's "Safety short: housekeeping at work," which gave instructions on how to hold a work-area training session that involved the active participation of employees. Information and guidance on the use of adult learning principles in developing training are available online. Examples include those posted by the U.S. Department of Education, the U.S. Department of Transportation (DOT), and the United Nations Environment Programme [Teaching Excellence in Adult Literacy 2010, 2011; U.S. DOT National Highway Institute 2003; United Nations Environment Programme 2015]. Additionally, participatory evaluation and training programs may be useful for improving ergonomics [van Eerd et al. 2010], as well as workplace safety and health in general [Henning et al. 2009; Arcury et al. 2010]. For example, a review article on the evaluation of cold environments stated that engaging employees in the evaluation and recommendation processes leads to solutions based on the specific conditions of the workplace and improves workers' acceptance of changes [Holmer 2009].

\section{Other Findings from Confidential Employee Interviews}

When we asked an open-ended question about health and safety concerns, $33(50 \%)$ of the interviewed employees reported concerns. The most frequently reported concerns were that certain equipment was broken or not working properly $(n=7)$ and that there were slippery floors $(n=4)$. Other concerns were only reported by three or fewer employees and are not listed in this report.

When we asked about the use of PPE, 64 (97\%) of the interviewed employees reported using plastic, cloth, or "other" gloves, 10 (15\%) of the interviewed employees reported using safety glasses, and $9(14 \%)$ reported using hearing protection. Sources of noise at this facility included noise from machines and noise caused by metal-on-metal contact involving carts, kitchen tools, and work surfaces. We did not measure employees' noise exposures or evaluate the hearing conservation program. Noise exposure measurements taken by the company's insurance carrier at another similar facility indicated that noise exposures were slightly below the OSHA action level and the NIOSH REL of 85 decibels, A-weighted. A noise survey would be necessary at this facility to determine if noise levels were different from those measured at the other facility.

\section{Conclusions}

Employees were exposed to a combination of risk factors for work-related musculoskeletal disorders, including awkward postures, forceful exertions, repetitive motions, job stress, and adverse psychosocial factors that could cause the musculoskeletal symptoms, injuries, and disorders we found. Employees were also exposed to workplace safety hazards that can lead 
to the types of acute traumatic incidents documented in the OSHA Logs. The temperatures we found in the freezers and coolers could explain employee reports of discomfort while working in the cold food kitchen and other departments. Employees also reported discomfort that they related to heat. Transportation department employees were also affected by outdoor temperature extremes. Dehydration related to increased sweat loss, the lack of drinking water in work areas, and limiting drinking of water to breaks could explain why employees reported that they did not have enough water to drink. We found dry ice used throughout the facility, including inside coolers that were not ventilated, despite a company prohibition, and where some employees spent the majority of the work shift. We measured high instantaneous levels of $\mathrm{CO}_{2}$ inside the coolers that require further evaluation. Most employees reported a moderate to high level of job stress. The most commonly reported job stressors were time pressure, high workload, and limited access to resources. One third of interviewed employees reported a lack of support from coworkers. The training materials and signs that we reviewed did not appear to fully meet the language and culturally appropriate needs of a diverse, multinational workforce.

\section{Recommendations}

On the basis of our findings, we recommend the actions listed below. We encourage the airline catering facility to use a labor-management health and safety committee or working group to discuss our recommendations and develop an action plan. Those involved in the work can best set priorities and assess the feasibility of our recommendations for the specific situations at the airline catering facility.

Our recommendations are based on an approach known as the hierarchy of controls. This approach groups actions by their likely effectiveness in reducing or removing hazards. In most cases, the preferred approach is to eliminate hazardous materials or processes and install engineering controls to reduce exposure or shield employees. Until such controls are in place, or if they are not effective or feasible, administrative measures and personal protective equipment may be needed.

\section{Ergonomics}

Many of the recommendations listed below were obtained from The Handbook of Ergonomic Design Guidelines [Humantech 2009]. The height recommendations below are for the North American population. When designing reaches, design for the smallest or shortest people in the working population. Do not design for the average; it excludes a majority of the working population.

1. Design for adjustability when possible.

- Standing hand working height should be adjustable from $38^{\prime \prime}-47$ " or fixed at 42".

- Part bins supporting the process should be placed in front of the employee with less than 16 " reaching distance at a vertical height of $24 "-70^{\prime \prime}$.

- More frequently used items or heavy items should be located 38"-49" above standing surface. 
- All work should be performed within 22" from the edge of the workstation (horizontal work distance guideline) to eliminate extended reaches.

2. Ensure that flow racks (such as the soda assembly and disassembly stations) have the following dimensions: $38^{\prime \prime}-49^{\prime \prime}$ retrieval height, $38^{\prime \prime}-62^{\prime \prime}$ replenish height, rack angles of $0^{\circ}-30^{\circ}$, and a minimum $5^{\prime \prime}$ clearance from the top of the bin to the bottom of the next shelf.

3. Provide tools to aid in reaching, such as a hook to pull material closer to the employee.

4. Provide lift tables or load levelers for palletized materials such as soda, beer, or water. A rotating top will help reduce reach distances when access is not available on three sides of the pallet.

5. Provide industrial mats for employees who stand for $90 \%$ or more of their working hours. Mats should be $\geq 0.5^{\prime \prime}$ thick, have an optimal compressibility of 3\%-4\%, have beveled edges to minimize trip hazards, and be placed at least 8 " under a workstation to prevent uneven standing surfaces. Mats should cover the entire area that employees move while performing their work task and be replaced when they appear worn out or are damaged.

6. Modify the standard operating procedures for lifting and moving pallets of bottled water to also include other palletized items, such as soda beverages. Employees should be reminded to keep heavy loads close to the body when lifting and carrying.

7. Cross-train employees who perform repetitive tasks on different jobs and rotate employees through jobs with different physical demands every 2 hours to reduce the stress on limbs and body regions.

8. Educate employees on musculoskeletal disorders and ergonomics, covering specific operations that have been identified by NIOSH or the company as causing or likely to cause musculoskeletal disorders.

9. Develop a system for employees to provide information and feedback on work equipment and procedure modifications.

10. Evaluate the effectiveness of engineering and administrative controls.

\section{Acute Traumatic Injuries}

1. Make sure floors are free of water, food, and obstacles to reduce slips, trips, and falls.

2. Repair uneven floors and maintain wheels on carts to reduce injuries caused by cart accidents.

3. Assure that information recorded on the OSHA 300 Logs is complete, particularly the descriptions of factors that contribute to incidents.

4. Evaluate OSHA Logs and investigate incidents to identify (a) priorities, such as causes of injuries with the highest days away from work, job restriction, or job transfer; (b) causes of injuries, particularly severe and irreversible ones, such as crush injuries and amputation; and (c) causes of the most frequent injuries. 


\section{Exposure to Cold Environments}

1. Rotate employees performing work requiring fine manual dexterity between warmer and colder areas throughout the workday. Rotating every 2 hours will also allow for breaks from cold temperatures.

2. Evaluate using thinner, fingertipless, or fingerless liner gloves that employees could wear under the required plastic gloves when performing work requiring fine manual dexterity.

3. Provide hand warmers (e.g., warm water or dry air heaters) outside of the coolers so employees can warm their hands periodically.

4. Implement a replacement schedule for gloves and other nondisposable PPE that includes checking for breakdown of the materials, excessive wear, tears, or other factors that may decrease their effectiveness.

5. Educate employees on the symptoms of cold stress as well as the importance of using the appropriate protective clothing and staying hydrated. Train employees in how to appropriately limit the effects of cold temperatures (e.g., appropriate use of PPE, changing wet clothing immediately, taking short breaks to warm hands).

6. Make sure all new trucks have heat.

\section{Exposure to Hot Environments}

1. Evaluate heat exposures of drivers during summer months. If needed, establish work/ rest schedules based on temperature, humidity, and the type of work. Provide medical surveillance, develop an emergency response procedure for heat-related injuries, and encourage employees to take regular breaks and to drink cool water throughout the work shift. For more information on heat stress and heat strain, see http://www.cdc. gov/niosh/topics/heatstress. An OSHA-NIOSH information sheet on heat illness that can be carried around by managers and employees is available at http://www.cdc.gov/ niosh/docs/2011-174.

2. Provide drinking water with disposable cups in all work areas. If water containers are used, they must be cleaned and refilled daily and kept away from heat.

3. Make sure all new trucks have air conditioning.

\section{Carbon Dioxide}

1. Enforce the prohibition of use or storage of dry ice in coolers unless ventilation in coolers is improved following ASHRAE guidelines [ASHRAE 2013] and personal monitoring of $\mathrm{CO}_{2}$ is performed. Place English and Spanish warning signs at cooler entrances prohibiting dry ice in the coolers.

2. Perform personal and area air monitoring for $\mathrm{CO}_{2}$ inside the coolers and other locations where dry ice is used to determine employees' exposures. If personal exposures exceed OELs, use engineering or work practice controls to reduce and control exposures. 
3. Label dry ice packaging and post warning signs in areas where dry ice is used and stored with the following wording, as recommended in NIOSH guidelines: "Solid carbon dioxide $\left(\mathrm{CO}_{2}\right)$ - Dry ice - Warning! Extremely cold $(-109 \mathrm{~F})$. Causes severe burns, liberates gas which may cause suffocation, avoid contact with skin and eyes; do not taste, do not put in stoppered or closed containers, and use and store only in wellventilated areas" [NIOSH 1976]. All labels and warnings should be printed in English and Spanish. Other means of communication would be necessary for employees who do not read English or Spanish.

4. Provide hazard communication training for employees with potential for exposure to $\mathrm{CO}_{2}$ from dry ice, such as employees working in the cooler and prep areas.

\section{Carbon Monoxide}

1. Maintain and inspect trucks following Environmental Protection Agency guidelines found at http://www.epa.gov/otaq/im.htm to identify high emission vehicles that need repair.

2. Make sure that dock doors remain closed while trucks are not docked to keep diesel exhaust from entering the building.

\section{Job Stress and Psychosocial Factors}

1. Explore further and address causes of job stress. An open discussion with employees may help identify job stressors, opportunities for improvement, and barriers to change. Otherwise, hiring a consultant with expertise in organizational psychology or a related field may be beneficial. The Society for Industrial and Organizational Psychology maintains a consultant locator at http://www.siop.org/consultantlocator/search.aspx. The American Society of Safety Engineers also maintains directories of qualified consultants at http://www.asse.org/practicespecialties/consultants/.

2. Ensure that employees are protected from retaliation when reporting their health and safety concerns to supervisors.

3. Evaluate whether increasing staff during peak hours would improve efficiency and lower job stress.

4. Ensure that all employees have the equipment necessary to complete their jobs before the beginning of a shift. If the necessary equipment is lacking, the need to purchase additional equipment or supplies should be addressed.

\section{Language, Communication, and Training}

1. Ensure that employees understand the potential hazards in their workplace and how to protect themselves. OSHA's hazard communication standard (29 CFR 1910.1200) requires that employees are informed and trained on potential work hazards and associated safe practices, procedures, and protective measures. Refer to the OSHA website for additional information: http:/www.osha.gov/pls/oshaweb/owadisp.show document?p table=standards\&p id=10099. 
2. Present all information (e.g., safety information, labels, warning signs, trainings, and messages) to employees in a manner that they are able to understand. When employees do not understand English, communication and training should be available in other languages. Alternative forms to written communication may be useful.

3. Use training and communication methods developed according to the principles of adult learning, multiple learning styles, effective messaging, and health communication. Examples and references in the section on language, communication, and training, are available under Findings and Discussion.

\section{Other Recommendations}

1. Improve ventilation in coolers where employees spend the majority of their shift to meet established ventilation guidelines in freezer or refrigerated areas $\left(<50^{\circ} \mathrm{F}\right)$ to provide indoor air quality that is acceptable to human occupants and that minimizes adverse health effects [ANSI/ASHRAE 2013].

2. Encourage all employees to report work-related symptoms (e.g., musculoskeletal, cold, and heat stress) to their supervisor without penalty. Employees with work-related symptoms should promptly seek medical attention from their healthcare provider. Certain chronic health conditions (for example, asthma, hypertension, diabetes) or certain medications can increase an individual's susceptibity to the effects of extreme heat and cold.

3. Determine whether the use of hearing protection is necessary in the workplace by conducting noise monitoring. If it is determined that hearing protection is necessary, integrate the proper use of this PPE in training and encourage supervisors to observe these practices and provide feedback, both positive and negative, to employees. 


\section{Appendix A: Occupational Exposure Limits and Health Effects}

NIOSH investigators refer to mandatory (legally enforceable) and recommended OELs for chemical, physical, and biological agents when evaluating workplace hazards. OELs have been developed by federal agencies and safety and health organizations to prevent adverse health effects from workplace exposures. Generally, OELs suggest levels of exposure that most employees may be exposed to for up to 10 hours per day, 40 hours per week, for a working lifetime, without experiencing adverse health effects. However, not all employees will be protected if their exposures are maintained below these levels. Some may have adverse health effects because of individual susceptibility, a pre-existing medical condition, or a hypersensitivity (allergy). In addition, some hazardous substances act in combination with other exposures, with the general environment, or with medications or personal habits of the employee to produce adverse health effects. Most OELs address airborne exposures, but some substances can be absorbed directly through the skin and mucous membranes.

Most OELs are expressed as a TWA exposure. A TWA refers to the average exposure during a normal 8- to 10-hour workday. Some chemical substances and physical agents have recommended STELs or ceiling values. Unless otherwise noted, the STEL is a 15-minute TWA exposure. It should not be exceeded at any time during a workday. The ceiling limit should not be exceeded at any time.

In the United States, OELs have been established by federal agencies, professional organizations, state and local governments, and other entities. Some OELs are legally enforceable limits; others are recommendations.

- The U.S. Department of Labor OSHA PELs (29 CFR 1910 [general industry]; 29 CFR 1926 [construction industry]; and 29 CFR 1917 [maritime industry]) are legal limits. These limits are enforceable in workplaces covered under the Occupational Safety and Health Act of 1970.

- NIOSH RELs are recommendations based on a critical review of the scientific and technical information and the adequacy of methods to identify and control the hazard. NIOSH RELs are published in the NIOSH Pocket Guide to Chemical Hazards [NIOSH 2010]. NIOSH also recommends risk management practices (e.g., engineering controls, safe work practices, employee education/training, personal protective equipment, and exposure and medical monitoring) to minimize the risk of exposure and adverse health effects.

- Other OELs commonly used and cited in the United States include the TLVs, which are recommended by ACGIH, a professional organization, and the workplace environmental exposure levels (WEELs ${ }^{\mathrm{TM}}$ ), which are recommended by the American Industrial Hygiene Association, another professional organization. The TLVs and WEELs are developed by committee members of these associations from a review of the published, peer-reviewed literature. These OELs are not consensus standards. TLVs are considered voluntary exposure guidelines for use by industrial hygienists and others trained in this discipline "to assist in the control of health hazards" [ACGIH 2015]. 
WEELs have been established for some chemicals "when no other legal or authoritative limits exist" [AIHA 2015].

Outside the United States, OELs have been established by various agencies and organizations and include legal and recommended limits. The Institut für Arbeitsschutz der Deutschen Gesetzlichen Unfallversicherung (Institute for Occupational Safety and Health of the German Social Accident Insurance) maintains a database of international OELs from European Union member states, Canada (Québec), Japan, Switzerland, and the United States. The database, available at http://www.dguv.de/ifa/GESTIS/GESTIS-Internationale-Grenzwerte-fürchemische-Substanzen-limit-values-for-chemical-agents/index-2.jsp, contains international limits for more than 1,500 hazardous substances and is updated periodically.

OSHA requires an employer to furnish employees a place of employment free from recognized hazards that cause or are likely to cause death or serious physical harm [Occupational Safety and Health Act of 1970 (Public Law 91-596, sec. 5(a)(1))]. This is true in the absence of a specific OEL. It also is important to keep in mind that OELs may not reflect current health-based information.

When multiple OELs exist for a substance or agent, NIOSH investigators generally encourage employers to use the lowest OEL when making risk assessment and risk management decisions. NIOSH investigators also encourage use of the hierarchy of controls approach to eliminate or minimize workplace hazards. This includes, in order of preference, the use of (1) substitution or elimination of the hazardous agent, (2) engineering controls (e.g., local exhaust ventilation, process enclosure, dilution ventilation), (3) administrative controls (e.g., limiting time of exposure, employee training, work practice changes, medical surveillance), and (4) PPE (e.g., respiratory protection, gloves, eye protection, hearing protection). Control banding, a qualitative risk assessment and risk management tool, is a complementary approach to protecting employee health. Control banding focuses on how broad categories of risk should be managed. Information on control banding is available at http://www.cdc.gov/niosh/topics/ctrlbanding/. This approach can be applied in situations where OELs have not been established or can be used to supplement existing OELs.

\section{Musculoskeletal Disorders and Ergonomics}

Musculoskeletal disorders are those conditions that involve the nerves, tendons, muscles, and supporting structures of the body. They can be characterized by chronic pain and limited mobility. Work-related musculoskeletal disorder refers to (1) musculoskeletal disorders to which the work environment and the performance of work contribute significantly, or (2) musculoskeletal disorders that are made worse or longer lasting by work conditions. A substantial body of data provides strong evidence of an association between musculoskeletal disorders and certain work-related factors (physical, work organizational, psychosocial, individual, and sociocultural). The multifactorial nature of musculoskeletal disorders requires a discussion of individual factors and how they are associated with work-related musculoskeletal disorders. Strong evidence shows that working groups with high levels of static contraction, prolonged static loads, or extreme working postures involving the neck/ shoulder muscles are at increased risk for neck/shoulder musculoskeletal disorders [NIOSH 
1997]. Further strong evidence shows job tasks that require a combination of risk factors (highly repetitious, forceful hand/wrist exertions) increase risk for hand/wrist tendonitis [NIOSH 1997]. Finally, strong evidence shows that low-back disorders are associated with work-related lifting and forceful movements [NIOSH 1997]. A number of personal factors can also influence the response to risk factors for musculoskeletal disorders: age, sex, smoking, physical activity, strength, and body measurements. Although personal factors may affect an individual's susceptibility to overexertion injuries/disorders, studies conducted in high-risk industries show that the risk associated with personal factors is small compared to that associated with occupational exposures [NIOSH 1997].

In all cases, the preferred method for preventing and controlling work-related musculoskeletal disorders is to improve the ergonomics of the workplace -- design jobs, workstations, tools, and other equipment to match the physiological, anatomical, and psychological characteristics and capabilities of the employee. Under these conditions, exposures to risk factors considered potentially hazardous are reduced or eliminated.

\section{Carbon Dioxide and Dry Ice}

$\mathrm{CO}_{2}$ is a colorless, odorless, and nonflammable gas [NIOSH 1976] that is normally present in our atmosphere at approximately $300-400 \mathrm{ppm}$. It is also a normal body constituent arising from cellular respiration. Commercial uses of solid $\mathrm{CO}_{2}$ (dry ice) primarily includes refrigeration of food. Dry ice is much colder than regular ice, and can severely freeze the skin like frostbite. Insulated gloves should be worn when handling dry ice. Safety glasses and a face shield should be worn when cutting or chipping it.

Dry ice can be a very serious hazard in a small space that is not well ventilated. As dry ice sublimes, it turns into $\mathrm{CO}_{2}$ gas. In a small space with poor ventilation, like a walk-in freezer or cooler, $\mathrm{CO}_{2}$ gas concentrations can build up. If enough $\mathrm{CO}_{2}$ gas is present, a person can become unconscious, and in some cases, die of suffocation because the $\mathrm{CO}_{2}$ will displace oxygen. Symptoms of overexposure to $\mathrm{CO}_{2}$ include headache and difficulty breathing, and with greater exposure, nausea and vomiting. The main health concerns associated with $\mathrm{CO}_{2}$ in levels above the OSHA PEL are narcosis, respiratory stimulation, or asphyxiation [OSHA 2015]. Exposure to high levels of $\mathrm{CO}_{2}$ may induce cardiopulmonary effects that can be reversed when removed from the environment (Halpern et al. 2004).

The NIOSH REL, OSHA PEL, and ACGIH TLV for $\mathrm{CO}_{2}$ are 5,000 ppm TWA; the NIOSH, OSHA, and ACGIH STELs are 30,000 ppm; and the immediately dangerous to life and health level is 40,000 ppm [NIOSH 2014a].

\section{Carbon Monoxide}

$\mathrm{CO}$ is produced by incomplete burning of carbon-containing materials such as diesel fuel. In previous evaluations of employees' exposures to diesel exhaust, NIOSH investigators have concluded that a potential health hazard exists when occupational exposures exceed ambient background levels - such as when diesel engines are operated in close proximity to work areas - and have recommended adopting measures to reduce exposures whenever feasible [NIOSH 1992, 1999]. 


\section{References}

ACGIH [2015]. 2015 TLVs ${ }^{\circledR}$ and BEIs ${ }^{\circledR}$ : threshold limit values for chemical substances and physical agents and biological exposure indices. Cincinnati, $\mathrm{OH}$ : American Conference of Governmental Industrial Hygienists.

AIHA [2015]. AIHA 2015 emergency response planning guidelines (ERPG) \& workplace environmental exposure levels (WEEL) handbook. Fairfax, VA: American Industrial Hygiene Association.

Arcury TA, Estrada JM, Quandt SA [2010]. Overcoming language and literacy barriers in safety and health training of agricultural workers. J Agromedicine 15(3):236-248.

ANSI/ASHRAE [2013]. Ventilation for acceptable indoor air quality. American National Standards Institute/ASHRAE standard 62.1-2013. Atlanta, GA: American Society of Heating, Refrigerating, and Air-Conditioning Engineers, Inc.

BLS [2015]. Injuries, illnesses, and fatalities. Industry injury and illness data. Supplemental news release tables. SNR05. Injury cases - rates, counts, percent relative standard errors detailed industry. U.S. Bureau of Labor Statistics, U.S. Department of Labor. [http://www. bls.gov/iif/oshsum.htm]. Date accessed: September 2015.

Cal/OSHA [2003]. Ergonomics in action: a guide to best practices for the food-processing industry. [http://www.dir.ca.gov/dosh/dosh publications/Erg Food Processing.pdf]. Date accessed: September 2015.

Cal/OSHA [2007]. Ergonomic guidelines for manual material handling. [http://www.cdc.gov/ niosh/docs/2007-131/pdfs/2007-131.pdf]. Date accessed: September 2015.

Canadian Centre for Occupational Health and Safety [2008]. Cold environments-working in the cold. [http://www.ccohs.ca/oshanswers/phys_agents/cold_working.html]. Date accessed: September 2015.

CFR. Code of Federal Regulations. Washington, DC: U.S. Government Printing Office, Office of the Federal Register.

Cheuvront SN, Kenefick RW [2014]. Dehydration: physiology, assessment, and performance effects. Compr Physiol 4(1):257-285.

Clark MM, Warren BA, Hagen PT, Johnson BD, Jenkins SM, Werneburg BL, Olsen KD [2011]. Stress level, health behaviors, and quality of life in employees joining a wellness center. Am J Health Promot 26(1):21-25.

Cox T, Griffiths A [2005]. The nature and measurement of work-related stress: theory and practice. In Wilson JR and Corlett N, eds. Evaluation of human work (3rd ed.). London: CRC Press, pp. 553-572.

Dababneh AJ, Swanson N, Shell RL [2001]. Impact of added rest breaks on the productivity and well being of workers. Ergonomics 44(2):164-174. 
Dahlström G, Granberg P-O, Holmér I [2011]. Cold environments and cold work. In: Vogt J-J (chapter editor). Heat and cold. In: Stellman JM (editor-in-chief). Encyclopedia of occupational health and safety. Geneva: International Labor Organization. [http://www. iloencyclopaedia.org/component/k2/76-42-heat-and-cold/cold-environment-and-coldwork? Itemid=422]. Date accessed: September 2015.

De Beeck RO, Hermans V [2000]. Research on work-related low back disorders (No. 204). [https://osha.europa.eu/en/tools-and-publications/publications/reports/204]. Date accessed: September 2015.

Faucett J, Meyers J, Milesc J, Janowitz I, Fathallah F [2007]. Rest break interventions in stoop labor tasks. Appl Ergon 38(2):219-226.

Galinsky T, Swanson N, Sauter S, Dunkin R, Hurrell J, Schleifer L [2007]. Supplementary breaks and stretching exercises for data entry operators: a follow-up field study. Am J Ind Med 50(7):519-527.

Halpern P, Raskin Y, Sorkine P, Oganezov A [2004]. Exposure to extremely high concentrations of carbon dioxide - a clinical description of a mass casualty incident. Ann Emerg Med 43(2):196-199.

Henning R, Warren N, Robertson M, Faghri P, Cherniack M, the CPH-NEW Research Team [2009]. Workplace health protection and promotion through participatory ergonomics: an integrated approach (practice article). Public Health Rep 124(S1):26-35.

Hess JA, Hecker S [2003]. Stretching at work for injury prevention: issues, evidence, and recommendations. Appl Occup Environ 18(5):331-338.

Humantech [2009]. The handbook of ergonomic design guidelines - Version 2.0. Ann Arbor, MI: Humantech, Inc.

IARC [1989]. IARC monographs on the evaluation of carcinogenic risks to humans: diesel and engine exhausts and some nitroarenes. Vol 46. Lyon, France: International Agency for Research on Cancer.

Kenney WL [2011]. Physiological responses to the thermal environment. In: Vogt J-J (chapter editor). Heat and cold. In: Stellman JM (editor-in-chief). Encyclopedia of occupational health and safety. Geneva: International Labor Organization. [http://www. iloencyclopaedia.org/component/k2/76-42-heat-and-cold/physiological-response-to-thethermal-environment?Itemid=422]. Date accessed: September 2015.

Mäkinen TM, Hassi J [2009]. Health problems in cold work (review). Ind Health 47(3):207-220.

NIOSH [1976]. NIOSH criteria for a recommended standard: occupational exposure to carbon dioxide. Cincinnati, OH: U.S. Department of Health, Education, and Welfare, Center for Disease Control, National Institute for Occupational Safety and Health, DHEW (NIOSH) Publication No. 76-194. [http://www.cdc.gov/niosh/docs/1970/76-194.html]. Date accessed: September 2015. 
NIOSH [1988]. Current intelligence bulletin 50: carcinogenic effects of exposure to diesel exhaust. Cincinnati, OH: U.S. Department of Health and Human Services, Centers for Disease Control, National Institute for Occupational Safety and Health, DHHS (NIOSH) Publication No. 88-116.

NIOSH [1992]. Health hazard evaluation report: Lancaster Fire Department, Lancaster, OH. Cincinnati, OH: U.S. Department of Health and Human Services, Centers for Disease Control and Prevention, National Institute for Occupational Safety and Health, NIOSH HHE Report No. 92-0160-2360.

NIOSH [1997]. Musculoskeletal disorders and workplace factors: a critical review of epidemiologic evidence for work-related musculoskeletal disorders of the neck, upper extremity, and low back. Cincinnati, OH: U.S. Department of Health and Human Services, Centers for Disease Control and Prevention, National Institute for Occupational Safety and Health, (DHHS) Publication No. 97-141. [http://www.cdc.gov/niosh/docs/97-141/]. Date accessed: September 2015.

NIOSH [1999]. Health hazard evaluation report: Costa Mesa Fire Department, Costa Mesa, CA. Cincinnati, OH: U.S. Department of Health and Human Services, Centers for Disease Control and Prevention, National Institute for Occupational Safety and Health, NIOSH HHE Report No. 99-0266-2850.

NIOSH [2009]. Work organization and stress-related disorders. [http://www.cdc.gov/niosh/ programs/workorg/]. Date accessed: September 2015.

NIOSH [2010]. NIOSH pocket guide to chemical hazards. Cincinnati, OH: U.S. Department of Health and Human Services, Centers for Disease Control and Prevention, National Institute for Occupational Safety and Health, DHHS (NIOSH) Publication No. 2010-168c. [http://www.cdc.gov/niosh/npg/]. Date accessed: September 2015.

NIOSH [2014a]. Documentation for immediately dangerous to life or health concentrations (IDLHs). Carbon dioxide. Cincinnati, OH: U.S. Department of Health and Human Services, Centers for Disease Control and Prevention, National Institute for Occupational Safety and Health [http://www.cdc.gov/niosh/idlh/124389.html]. Date accessed: September 2015.

NIOSH [2014b]. Health hazard evaluation report: evaluation of ergonomic risk factors, thermal exposures, and job stress at an airline catering facility. By Ramsey JG, Musolin K, Ceballos D, Wiegand D, Mead K. Cincinnati, OH: U.S. Department of Health and Human Services, Centers for Disease Control and Prevention, National Institute for Occupational Safety and Health, NIOSH HHE Report No. 2011-0131-3221. [http://www.cdc.gov/niosh/ hhe/reports/pdfs/2011-0131-3221.pdf]. Date accessed: September 2015.

OSHA [2010]. OSHA training standards policy statement (memorandum). [https://www.osha. gov/dep/standards-policy-statement-memo-04-28-10.html]. Date accessed: September 2015.

OSHA [2015]. Carbon dioxide. U.S. Department of Labor, Occupational Safety and Health Administration. [https://www.osha.gov/dts/chemicalsampling/data/CH 225400.html]. Date accessed: September 2015. 
Piedrahita H [2008]. Working in cold conditions indoors: effects of musculoskeletal symptoms and upper limb movements. Doctoral thesis. Luleå University of Technology. ISSN: $1402-1544$.

Teaching Excellence in Adult Literacy [2010]. Student-centered learning (TEAL Center fact sheet no. 6). U.S. Department of Education, Office of Vocational and Adult Education, The Teaching Excellence in Adult Literacy Center. [https://teal.ed.gov/sites/default/files/FactSheets/6\%20 TEAL_Student-Centered.pdf]. Date accessed: September 2015.

Teaching Excellence in Adult Literacy [2011]. Adult learning theories (TEAL Center fact sheet no. 11). U.S. Department of Education, Office of Vocational and Adult Education, The Teaching Excellence in Adult Literacy Center. [https://teal.ed.gov/sites/default/files/FactSheets/11 \%20TEAL_Adult_Learning_Theory.pdf]. Date accessed: September 2015.

United Nations Environment Programme [2015]. What is necessary to know about interactive training. In: More on developing and delivering training. United Nations Environment Programme. [http:/www.unep.org/ieacp/iea/training/guide/default.aspx?id=1185]. Date accessed: September 2015.

U.S. DOT National Highway Institute [2003]. National instructor development course: principles of adult learning and instructional systems design. [http://www.nhi.fhwa.dot.gov/ downloads/freebies/172/PR\%20Pre-ourse\%20Reading\%20Assignment.pdf]. Date accessed: September 2015.

van Eerd D, Cole D, Irvin E, Mahood Q, Keown K, Theberge M, Village J, St. Vincent M, Cullen K [2010]. Process and implementation of participatory ergonomic interventions: a systematic review. Ergonomics 53(10):1153-1166.

World Health Organization [2010]. Health impact of psychosocial hazards at work: an overview. [http://whqlibdoc.who.int/publications/2010/9789241500272 eng.pdf]. Date accessed: September 2015.

Warren N [2001]. Work stress and musculoskeletal disorder etiology: the relative roles of psychosocial and physical risk factors. Work 17(3):221-234.

Washington State Department of Labor and Industries [2005]. Fitting the job to the worker: an ergonomics program guide. [https://ergoweb.com/knowledge/ergonomics-101/standards/ fitting-the-job-to-the-worker/]. Date accessed: September 2015. 
Keywords: North American Industry Classification System 722310 (Food Service

Contractors), New York, airline catering, musculoskeletal disorders, ergonomics, acute traumatic injuries, indoor cold environments, carbon dioxide, job stress, language barriers 
This page left intentionally blank 
The Health Hazard Evaluation Program investigates possible health hazards in the workplace under the authority of the Occupational Safety and Health Act of 1970 (29 U.S.C. § 669(a) (6)). The Health Hazard Evaluation Program also provides, upon request, technical assistance to federal, state, and local agencies to investigate occupational health hazards and to prevent occupational disease or injury. Regulations guiding the Program can be found in Title 42, Code of Federal Regulations, Part 85; Requests for Health Hazard Evaluations (42 CFR Part 85).

\section{Disclaimer}

The recommendations in this report are made on the basis of the findings at the workplace evaluated and may not be applicable to other workplaces.

Mention of any company or product in this report does not constitute endorsement by NIOSH.

Citations to Web sites external to NIOSH do not constitute NIOSH endorsement of the sponsoring organizations or their programs or products. NIOSH is not responsible for the content of these Web sites. All Web addresses referenced in this document were accessible as of the publication date.

\section{Acknowledgments}

Literature Review: Kathleen Connick

Desktop Publisher: Shawna Watts

Editor: Ellen Galloway

Logistics: Donnie Booher, Kevin Moore

\section{Availability of Report}

Copies of this report have been sent to the employer, employees, and union at the facility.

The state and local health department and the Occupational Safety and Health Administration

Regional Office have also received a copy. This report is not copyrighted and may be freely reproduced.

This report is available at http://www.cdc.gov/niosh/hhe/reports/pdfs/2011-0131-3222.pdf.

\section{Recommended citation for this report:}

NIOSH [2015]. Health hazard evaluation report: evaluation of ergonomic risk factors, acute traumatic injuries, and occupational exposures at an airline catering facility. By Ramsey J, Kawamoto M, Ceballos D, Wiegand, DM. Cincinnati, OH: U.S. Department of Health and Human Services, Centers for Disease Control and Prevention, National Institute for Occupational Safety and Health, NIOSH HHE Report No. 2011-0131-3222. 
Delivering on the Nation's promise:

Safety and health at work for all people through research and prevention

To receive NIOSH documents or more information about occupational safety and health topics, please contact NIOSH:

Telephone: 1-800-CDC-INFO (1-800-232-4636)

TTY: 1-888-232-6348

CDC INFO: www.cdc.gov/info

or visit the NIOSH Web site at www.cdc.gov/niosh

For a monthly update on news at $\mathrm{NIOSH}$, subscribe to

$\mathrm{NIOSH}$ eNews by visiting www.cdc.gov/niosh/eNews. 